NBER WORKING PAPER SERIES

\title{
COMPETITION IN THE AUDIT MARKET: POLICY IMPLICATIONS
}

\author{
Joseph J. Gerakos \\ Chad Syverson \\ Working Paper 19251 \\ http://www.nber.org/papers/w19251
NATIONAL BUREAU OF ECONOMIC RESEARCH
1050 Massachusetts Avenue
Cambridge, MA 02138 \\ July 2013
}

We thank Ray Ball, Mary Barth, J.P. Dubé, Ron Goettler, Bobby Gramacy, Guenter Hitsch, Ali Hortaçsu, Bill Kinney, Dave Larcker, Christian Leuz, Doug Shackelford, Jesse Shapiro, Doug Skinner, Stephen Taylor, Anne Vanstraelen, Mike Willenborg, and workshop participants at Maastricht University, Ohio State University, Stanford University, University of Chicago, University of Connecticut, University of Melbourne, University of North Carolina, University of Technology, Sydney, and the 2012 Illinois Audit Symposium for their comments. The views expressed herein are those of the authors and do not necessarily reflect the views of the National Bureau of Economic Research.

At least one co-author has disclosed a financial relationship of potential relevance for this research. Further information is available online at http://www.nber.org/papers/w19251.ack

NBER working papers are circulated for discussion and comment purposes. They have not been peerreviewed or been subject to the review by the NBER Board of Directors that accompanies official NBER publications.

(C) 2013 by Joseph J. Gerakos and Chad Syverson. All rights reserved. Short sections of text, not to exceed two paragraphs, may be quoted without explicit permission provided that full credit, including (c) notice, is given to the source. 
Competition in the Audit Market: Policy Implications

Joseph J. Gerakos and Chad Syverson

NBER Working Paper No. 19251

July 2013

JEL No. D43,G3,K22,L13,L84,M42

\begin{abstract}
$\underline{\text { ABSTRACT }}$
The audit market's unique combination of features-its role in capital market transparency, mandated demand, and concentrated supply-means it receives considerable attention from policymakers. We explore the effects of two market scenarios that have been the focus of policy discussions: a) further supply concentration due to one of the "Big 4" auditors exiting and b) mandatory audit firm rotation. To do so, we first estimate publicly traded firms' demand for auditing services, treating services provided by each of the Big 4 as differentiated products. We then use those estimates to calculate how each scenario would affect client firms' consumer surplus. We estimate that, conservatively, exit by one of the Big 4 would reduce client firms' surplus by \$1.2-1.8 billion per year. These estimates reflect only firms' lost options to hire the exiting auditor; they do not include the likely fee increases resulting from less competition among auditors. We calculate that the latter could result in audit fee increases between \$0.3-0.5 billion per year. Such losses are substantial; by comparison, total audit fees for public firms were $\$ 11$ billion in 2010 . We find similarly large impacts from mandatory audit firm rotation, estimating consumer surplus losses at approximately $\$ 2.4-3.6$ billion if rotation were required after ten years and \$4.3-5.5 billion if rotation were mandatory after only four years.
\end{abstract}

Joseph J. Gerakos

University of Chicago

5807 S. Woodlawn Avenue

Chicago, IL 60637

jgerakos@chicagobooth.edu

Chad Syverson

University of Chicago

Booth School of Business

5807 S. Woodlawn Ave.

Chicago, IL 60637

and NBER

chad.syverson@chicagobooth.edu 


\section{Introduction}

The market for financial audits exhibits a set of features that distinguish it from other markets for business services (and for that matter, many other goods more broadly). First, it is seen by many to play an important and in some ways unique role in preserving transparency and improving the functioning of capital markets (e.g., Watts and Zimmerman (1983), Black (2001), and Ball (2001)). Relatedly, failures of auditors to catch and report improprieties are often highly - and occasionally spectacularly — visible.

Second, a substantial portion of demand in the market is mandated. Publicly traded firms are compelled to purchase audit services, and there are no services from outside the industry that can legally serve as substitutes.

Third, the market's supply side is highly concentrated. Among publicly traded companies in the U.S., for example, the majority of audit engagements and almost all audit fees involve just four audit firms (the "Big 4": Ernst \& Young, Deloitte Touche, KPMG, and PricewaterhouseCoopers). In 2010 the Big 4 handled $67 \%$ of audit engagements and collected over $94 \%$ of audit fees. (For a breakdown of market shares over the recent decade, see Table 1.) As discussed by Velte and Stiglbauer (2012), similar concentration is observed in the audit markets of many other developed economies.

The combination of these features has resulted in the audit industry being subject to frequent policy debates. In this paper, we explore two oft-recurring discussions in this vein. The first regards the effects of further concentration in supply due to one of the Big 4 audit firms exiting the market. The second involves the consequences of imposing a mandatory audit firm rotation policy.

Both of these scenarios have already colored policy toward the industry. There have been 
several recent cases in which a Big 4 audit firm could arguably have been criminally indicted but the Department of Justice decided to not file charges, probably because of concerns about further increasing concentration. ${ }^{1}$ For example, in 2005 KPMG admitted criminal wrongdoing by creating tax shelters that helped clients evade $\$ 2.5$ billion in taxes. Nevertheless, the Department of Justice did not indict KPMG and instead entered into a deferred prosecution agreement (Johnson (2010)). Moreover, according to the Lehman Brothers bankruptcy examiner's report (Valukas (2010)), Ernst \& Young assisted Lehman Brothers in implementing its Repo 105 transactions, which allowed Lehman to temporarily reduce its leverage when preparing its financial statements. Nonetheless, the Department of Justice did not pursue criminal charges against Ernst \& Young. ${ }^{2}$

With regard to mandatory auditor rotation, the Public Company Accounting Oversight Board (the "PCAOB") is in active discussions about implementing such a policy for SEC registrants. During the PCAOB's hearings in March 2012 on mandatory audit firm rotation, panelists voiced opposing views about the costs and benefits of mandatory audit firm rotation. For example, the executive director of the AICPA's Center for Audit Quality stated that mandatory audit firm rotation would hinder audit committees in their oversight of external auditors, while former SEC chairman Arthur Levitt supported mandatory rotation because "investors deserve the perspectives of different professionals every so often, particularly when an auditor's independence can be reasonably called into question" (Tysiac (2012)). Moreover, in June 2013 the House Financial Services Committee unanimously passed a bill to prohibit the PCAOB from mandating audit firm rotation (Cohn (2013)).

We seek to explore how the fruition of these two scenarios - the disappearance of one of the Big 4 and the imposition of mandatory auditor rotation - would affect the audit market, and in

\footnotetext{
${ }^{1}$ A criminal conviction prohibits an audit firm from carrying out audits of SEC registrants.

${ }^{2}$ In contrast, the New York attorney general Andrew Cuomo sued Ernst \& Young claiming that the audit firm helped Lehman "engage in a massive accounting fraud" (Public Accounting Report (2011)).
} 
particular the consequences for publicly traded firms, its primary customers. Addressing these questions satisfactorily requires, at the very least, measurements of the willingness of firms to substitute among individual auditors and the value firms place (if any) on extended relationships with auditors. However, prior research on the structure of the audit market has focused primarily on either correlations between audit fees and firm characteristics or substitutability between the Big 4 and non-Big 4 auditor groups. ${ }^{3}$ While this work has offered insights to several questions, its focus has left a gap that we seek to begin to fill with this study.

Our empirical approach treats the audit market much like any other differentiated product market (even the mandatory nature of demand can easily be handled within our framework). ${ }^{4}$ We model firms seeking audit services as choosing from among several producers of those services (i.e., the audit firms), with each potential auditor offering varying aspects of service that are potentially valued differentially by each client firm. ${ }^{5}$ Each publicly listed firm considers how well the attributes of each auditor's product match its needs (these attributes include price - the audit fees) and hires the auditor offering the best net value.

With this factor demand framework, we can use data on publicly listed firms' choices of auditors to measure via revealed preference how firms view the audit services provided by each of the Big 4 auditors as well as by smaller audit service providers. Importantly, we can quantify a firm's willingness to substitute among auditors. That is, we can compute the dollar transfer that would be necessary to make a client switch to a different auditor. In particular, we are able to calculate the transfer necessary to compensate client firms who lose a potential auditor choice due to exit

\footnotetext{
${ }^{3}$ For examples of studies that examine substitutability between the Big 4 and non-Big 4 groups, see Willenborg (1999), Ettredge, Kwon, and Lim (2009), and Lennox, Francis, and Wang (2012)

${ }^{4}$ Our empirical approach neither assumes nor imposes differentiation. It instead allows for differentiation among the Big 4 audit firms and lets the data speak as to its existence. In this way, it contrasts with prior research that assumes no differentiation among the Big 4 (e.g., Doogar and Easley (1998) and Sirois and Simunic (2013)).

${ }^{5}$ Because audits are inputs into firms' production activities, these are differentiated factor markets, but the economics are essentially the same as in markets for differentiated outputs.
} 
of a Big 4 auditor, as well as to quantify clients' willingness to pay for longer-term relationships with a particular auditor, and hence what value the client firms would lose if forced to break such relationships because of mandatory auditor rotation. Thus we can address quantitatively some of the key policy questions surrounding the issues of further auditor concentration and mandatory auditor rotation.

Our analyses indicate that the exit of any of the Big 4 auditors would result in substantial losses in client firms' expected consumer surplus (that is, the firms' value of their purchased audit services in excess of the fees they pay for them; the net benefit they derive from the audit services). We estimate that, conservatively, client firms' consumer surplus will fall by between $\$ 1.2-1.8$ billion per year. This loss in surplus can be interpreted as the total amount of cash transfers client firms would require to compensate them for losing the ability to hire the exiting auditor. These figures reflect only the direct effect of the loss of auditor choice; they do not account for the likely increases in audit fees that would occur due to less competition among the remaining auditors. Using our data to estimate the latter effect, we calculate moving from the Big 4 to the Big 3 could result in audit fee increases between $\$ 0.3-0.5$ billion per year. These higher fees correspond dollar-for-dollar with lost consumer surplus among client firms, so this supply response effect exacerbates the pure choice effect. Both of these losses are substantial; by comparison, total audit fees for public firms were $\$ 11$ billion in 2010 .

We find similarly large impacts from mandatory audit firm rotation, estimating consumer surplus losses at approximately $\$ 2.4-3.6$ billion if rotation were required after ten years (with the higher estimated losses reflecting the anticipated fee setting responses of auditors to the new market rules) and $\$ 4.3-5.5$ billion if rotation were mandatory after only four years.

These estimates carry several caveats. First, the Big 4 audit firms operate worldwide, while 
our estimates are based only upon their U.S. public clients. Second, due to a lack of data we are also unable to include in our analysis private firms, though they would also suffer losses in surplus. Finally, our estimates are limited to audit fees and services and do not take into account non-audit and audit-related fees and services. Nevertheless, these estimates are informative about the costs that could arise from changes in the audit industry's market structure and from the implementation of mandatory rotation. ${ }^{6}$ In addition, they provide some of the first estimates of the value of audit firm-client matches.

The analyses in this paper are obviously relevant to those directly interested in the specific policy-relevant counterfactuals in the audit industry that we examine in this paper. However, we believe more general lessons can also be drawn from the analyses. They offer a framework for investigating sets of demand, supply, and competitive issues in the audit market that extend well beyond the two we investigate here. Indeed, there are entire literatures dedicated to examining these issues, an attention reflecting in part the audit market's special role in helping capital markets function. Our framework, which has been applied in similar forms in other market settings but (to our knowledge) is novel to research on the audit market, lets researchers quantify and isolate demand- and supply-side fundamentals that allow fuller answers to questions about the nature and effects of the market than the previous literature has been able to deliver. Further, the approach here can be applied to address research questions about the markets for business services more broadly, which are extensive in size and scope.

Our analysis is structured as follows. We first discuss how we model client firms' choices of auditor. We then describe the estimation of our demand model, including our approaches for dealing with price endogeneity. We also explain how we handle a more atypical situation in demand

\footnotetext{
${ }^{6}$ There may be benefits from mandatory auditor rotation as well. Quantifying those benefits requires an analytical approach that is beyond the scope of this paper, however. Our estimates here offer a measurement of the costs of rotation that an optimal policy would balance any benefits against.
} 
estimation, the fact that we do not observe prices (fees) for producers (auditors) that a firm does not hire. Then, after reporting and discussing our demand estimates, we use these estimates to calculate the expected effects of the two counterfactual scenarios described above: greater audit industry concentration and mandated auditor rotation.

\section{Demand Model}

We model publicly listed firms' demand for audit services as reflecting a choice among several potential auditors: each of the Big 4 and an amalgam outside good that includes all other audit

firms. Every client firm makes its choice based on the expected benefit it would obtain from hiring each of the auditors. This benefit includes the effects of both firm-, auditor-, and match-specific attributes and is net of the fees the auditor charges the client firm for its service.

While the discrete choice demand model we lay out below is in many ways standard in the industrial organization literature, our approach differs from the substantial prior literature on auditor choice in that this work has typically examined the determinants of the simple dichotomous choice between using a Big 4 versus a non-Big 4 auditor. Our analytical structure allows us to characterize much more fully the patterns of substitution among the individual auditors, and just as importantly lets us tie client firms' choices directly to parameters of their factor demands, which is key to quantifying preferences in terms of dollar values.

\subsection{Utility Specification}

For firms' choice of auditor, we specify the "inside" goods as the Big 4 auditors (Ernst \& Young, Deloitte Touche, KPMG, and PricewaterhouseCoopers) and the "outside" good as the aggregation 
of all other auditors who provide audits to public firms (BDO Seidman, Grant Thornton, etc.). Because we are identifying the preference parameters of publicly listed firms whose demand for audit services is mandated, there is no true outside good in this setting. Thus we can simply define the outside good as any auditor choice not in the Big 4. Mandated demand makes our task easier, as we do not need to be concerned with defining the full breadth of potential demand for the market, a necessary assumption in discrete choice settings where buyers might not purchase any product in the market.

We model each client firm i's utility from choosing auditor $\mathrm{j}$ as

$$
U_{i j}=\delta_{j}-\alpha \ln \left(p_{i j}\right)+\beta_{i j} x_{i j}+\epsilon_{i j}
$$

in which $\delta_{j}$ is an auditor fixed effect that represents the mean utility that all potential clients obtain from choosing auditor $\mathrm{j}$ (this variable subsumes brand effects and any other attributes of j's services that all potential clients value equally); $p_{i j}$ is auditor $\mathrm{j}$ 's price for an audit of firm i (i.e., its audit fees); $\alpha$ parameterizes the marginal willingness to pay for a log-dollar of audit fees; $x_{i j}$ is a vector of observable non-price characteristics of the client-auditor pair; $\beta_{i j}$ are the utility loadings on these characteristics, and $\epsilon_{i j}$ represents an unobserved client-auditor specific component of utility assumed to be independently and identically distributed. ${ }^{7}$ In our specification, audit fees enter in logarithmic form. This implies that an additional dollar of audit fees matters less to a large client than a small client. This specification is consistent with clients negotiating with auditors over percentage changes in audit fees rather than absolute dollar changes.

To model the interactions between non-price characteristics of the client firm and the auditor, we expand $\beta_{i j} x_{i j}$ as follows. First, we interact the auditor fixed effect, $\delta_{j}$, with the natural logarithm of

\footnotetext{
${ }^{7}$ While we have labeled equation (1) as describing a client firm's utility, it can be interpreted more broadly as any objective function of the client with respect to its audit firm choice.
} 
the client's size, $\ln \left(\right.$ TotalAssets $\left._{i}\right)$. This interaction allows us to capture audit firm preferences that vary with client firm scale. For example, smaller firms may prefer non-Big 4 auditors, and there could be heterogeneous size-based preferences across each of the Big 4 auditors. Second, we interact the auditor fixed effects with an additional set of client characteristics commonly used in the audit literature: $\ln \left(\right.$ Segments $\left._{i}\right)$ is the natural logarithm of the number of industrial segments in which the client operators; Foreign Sales $_{i}$ is the ratio of foreign to total sales; Debt $t_{i}$ is the ratio of short plus long-term debt to total assets; $R O A_{i}$ is the client's return on assets; Inventory + Receivables $_{i}$ is the ratio of inventory plus accounts receivables to total assets; Payables $i$ is the ratio of accounts payable to total assets. These interactions allow rich variation in preferences for auditors across client firms with different operating and financial characteristics. Fourth, we further interact $\delta_{j}$ with industry indicators (using the Fama-French ten-industry classification system) to control for any systematic preference differences across clients' industries.

While firms in principle choose their auditor every year, the data reveal a strong tendency to rehire the previous year's auditor. This persistence can be seen in Table 2, which shows the transition matrix for client firms' auditor choices in consecutive years over the period 2008-2010. The largest elements in the matrix by some distance are its diagonals; the probability of renewing an existing auditor relationship is in the neighborhood of $95 \%$. This persistence could reflect the effect of match-specific capital formed during the course of an auditing relationship or reveal the strength of some other match-specific unobservable utility component that makes retention more likely. To parsimoniously incorporate any such effects, we add elements to equation (1) that allow for the possibility that re-choosing the prior year's auditor will deliver additional utility. Specifically, we interact the auditor fixed effects with two additional variables: an indicator that equals one if the client firm did not use the respective auditor in the prior year, $1\left(\right.$ Not client $\left._{i j}\right)$, and the natural logarithm of the number of consecutive years that the client firm has hired to its current auditor, 
$\ln \left(\right.$ YearsClient $\left._{i j}\right) .^{8}$

Given this utility function, a client firm's choice decision is straightforward. Client i calculates $U_{i j}$ for each of its five options (the Big 4 firms and the outside good) and then chooses the audit firm $\mathrm{j}$ that provides the maximum $U_{i j}$.

\subsection{Estimation}

Equation (1) can be written as $U_{i j}=V_{i j}+\epsilon_{i j}$, in which $V_{i j} \equiv \beta_{i j} x_{i j}-\alpha \ln \left(p_{i j}\right)+\delta_{j}$ is the observable portion of utility, and $\epsilon_{i j}$ is the unobserved portion of utility. If we assume that $\epsilon_{i j}$ is distributed type 1 extreme value, the predicted probability that client $\mathrm{i}$ chooses audit firm $\mathrm{j}$ is

$$
P_{i j}=\frac{e^{V_{i j}}}{\Sigma_{j} e^{V_{i j}}} .
$$

This specification is the standard conditional logit commonly used in the industrial organization and marketing literatures to estimate demand for discrete differentiated products. ${ }^{9}$ The conditional logit is similar to a fixed effect regression in that any characteristic of client i that does not vary across choices (here, auditors) drops out of equation (2). For example, firm size itself drops out of equation (2); only interactions between firm size and the auditor fixed effects remain to influence choice probabilities.

If $y_{i j}=1$ represents that client $\mathrm{i}$ chooses auditor $\mathrm{j}$ and zero otherwise, then the log likelihood

\footnotetext{
${ }^{8}$ We define this latter variable as zero for Big 4 firms that are not the client firm's current auditor; thus the "not current auditor" indicator coefficient reflects the difference in demand between an auditor with which the client firm does not have a current relationship and an auditor with which the client has been matched for one year.

${ }^{9}$ For a discussion, see Train (2009). For an application, see Petrin (2002).
} 
corresponding to $(2)$ is:

$$
L L(\alpha, \beta, \delta)=\sum_{i} \sum_{j} y_{i j} \ln P_{i j}=\sum_{i} \sum_{j} y_{i j} \ln \frac{e^{V_{i j}}}{\Sigma_{j} e^{V_{i j}}}
$$

We maximize this log likelihood to obtain estimates of the utility/preference parameters $\alpha, \beta$, and $\delta$.

\section{$2.3 \quad$ Prices}

The price/fee term of equation (1) raises a few estimation issues.

\subsubsection{Missing Fees}

One issue with equation (1) is that we only observe prices (audit fees) for actual matches between clients and auditors. This is an unusual situation in demand estimation settings; the researcher typically observes the prices of each item of the available choice set. We must therefore estimate what fees a client would have expected to pay had it hired an audit firm other than the one it ended up choosing.

We implement these "what if" prices using a predictive model estimated from the relationships between the fees in observed client-auditor matches and client-, auditor-, and match-specific characteristics. We considered several prediction methods including ordinary least squares, lasso regression, ridge regression, partial least squares, and two regression tree approaches (random partitioning and random forest). ${ }^{10}$ Based on root mean squared error derived from cross-fold validation, we found that regression trees (specifically, random forest) best predict dollar audit fees using the

\footnotetext{
${ }^{10}$ For a discussion of these methods, see Hastie, Tibshirani, and Friedman (2009).
} 
following set of predictor variables: total assets, the number of industrial segments the firm operates in, foreign sales, debt, return on assets, inventory \& receivables, indicators to capture whether and for how long the firm was a client of the auditor (all of the preceding are characteristics of the client firm), and indicators for the Fama-French nine-industry classification. These are the same variables included in our demand estimation and are commonly used in reduced form regressions of audit fees (Hay, Knechel, and Wong (2006)).

In our demand estimations, we use predicted fees in equation (1) for all auditors, including the actual audit firm chosen by the client. We do so because it is likely that the prices associated with actual choices include a negative price shock that would otherwise bias our estimated price coefficients toward zero. For a discussion of this issue, see Erdem, Keane, and Sun (1999).

\subsubsection{Price Endogeneity}

A major concern in most demand estimation settings is the possibility of price endogeneity (i.e., $\left.\operatorname{cov}\left(p_{i j}, \epsilon_{i j}\right) \neq 0\right)$. For example, if price is positively correlated with unobserved audit quality — say because client firms have a greater willingness to pay for higher quality audits and/or auditors have higher costs of delivering them - then the coefficient on price will be positively biased (toward zero, given that theory predicts the coefficient should be negative). The resulting demand estimates would make it appear that firms are less sensitive to audit fees than they really are. A way to avoid this bias is to identify firms' price sensitivity using fee variation that is driven by supply-side factors that are uncorrelated with demand shifts $\left(\epsilon_{i j}\right)$. We are fortunate to have in our market setting and data two sets of supply shifters that we can use in our audit fee prediction regressions to aid in this identification. One uses the change in supply structure induced by the sudden and unexpected exit of Arthur Andersen from the market, and the second uses exogenous increases in auditor supply 
created by client mergers and acquisitions. We describe each in further detail below.

Disappearance of Arthur Andersen We use the collapse of Arthur Andersen in 2002 due to its post-Enron conviction (later overturned, though too late to revive Arthur Andersen as an auditing firm) as an exogenous shock to supply in the audit market. The collapse of Arthur Andersen reduced competition among auditors, creating an opportunity for the remaining suppliers to increase their audit fees. Prior research on auditor specialization (e.g., Craswell, Francis, and Taylor (1995), Hogan and Jeter (1999), and Casterella, Francis, Lewis, and Walker (2004)) implies this supply shock was industry specific: the supply shift was larger in industries where Andersen had a greater share of the audit market before its collapse (in terms of Andersen's client firms' share of industry assets). This across-industry variation is useful because while one might be concerned that Andersen's collapse might be intertemporally linked with changes in the demand for auditing services (due to the passage of Sarbanes-Oxley, for example), it is unlikely that these demand shifts would be systematically related to Andersen's prior share of the industry market. Thus the crossindustry variation in Andersen's pre-collapse share offers a source of supply-driven price variation that is likely orthogonal to shifts in the demand for auditing services.

To empirically validate the disappearance of Arthur Andersen as relevant to observed changes in audit fees, Table 3 shows the results of regressing the log difference in client firms' audit fees on Andersen's 2001 market share in the firms' respective three-digit SIC industries, Andersen's Share. If our argument that Andersen's collapse is an inward shift in audit supply is correct, the coefficient on Andersen's Share will be positive. That is, publicly traded firms in industries where Andersen was more dominant before its collapse will see a greater increase in fees afterwards, regardless of whether they were Andersen clients themselves. 
We estimate these regressions separately for 2008, 2009, and 2010. We include as additional controls indicator variables for the firm's auditor in 2001 to account for any systematic differences in fee growth tied to the client's auditor. (For example, the fee growth for Andersen clients may differ from the fee growth for firms that were Ernst \& Young clients in 2001.) We also include the change in the client's logged total assets over each period, as the prior literature has found that total assets are the most important predictor of audit fees. We cluster the standard errors by three-digit SIC. Because we require that the data be available over each change interval, the sample size drops monotonically from 2,806 clients for 2001-2008 to 2,399 clients for 2001-2010.

The results, presented in Panel A of Table 3, indicate that the coefficient on the supply shifter Andersen's Share is indeed positive at every horizon and statistically significant for all horizons. In other words, industries in which Andersen had a larger market share before its collapse experienced greater growth in audit fees afterwards, and this effect persisted at least through $2010 .{ }^{11}$

An alternative explanation for these results is that Arthur Andersen charged lower prices and provided lower quality audits, thereby leading to greater increases in audit fees for Andersen clients. However, we do not believe that such an effect drives the results presented in Table 3 for two reasons. First, Cahan, Zhang, and Veenman (2011) find that prior to the Enron scandal, Arthur Andersen provided audits of similar quality to the audits provided by the other major audit firms. Second, as seen in Panel B, we find similar effects if we limit the sample to firms that were not Andersen clients.

Given the results in Table 3, we include Andersen's Share in the annual audit fee prediction regressions. This variable offers variation in audit fees due to supply shocks that should be uncorrelated with clients' relative demand for surviving auditors, allowing us to obtain unbiased estimates

\footnotetext{
${ }^{11}$ We find similar results for the years 2002 through 2007.
} 
of the sensitivity to fee changes of client firms' auditor choices.

Client Mergers and Acquisitions Our second source of supply-driven audit fee variation exploits mergers and acquisitions among client firms. Because each firm only needs a single auditor, a merger or acquisition involving firms with different auditors will result in one auditor being dropped. The audit firm that loses a client will find itself with excess capacity that should put downward pressure on audit fees. Supply can also shift even if both pre-merger client firms have the same auditor, because even though the merged firm requires greater auditing, the elasticity of audit fees to total assets is approximately 0.3-0.4; some of the auditor's overhead is duplicative and can be freed for other uses. This creates excess audit capacity for the merged firm's auditor and the resulting price effects. These supply shifts will be orthogonal to audit demand shocks as long as client-level mergers and acquisitions are driven by neither auditor choice nor audit fee considerations, which strike us as quite likely.

To test whether mergers and acquisitions have the expected effects on audit fees, we regress client firms' logged fees on the prior year's ratio of merged to total assets the firms' respective three-digit SIC industries, Merged Assets. We also control for the ratio of receivables to assets, the ratio of inventories to assets, the return on assets, an indicator variable for whether the client experienced a loss, the percent of foreign sales, the natural logarithm of the number of industrial segments, an indicator for whether the firm is an accelerated filer, ${ }^{12}$ and firm, industry, and year fixed effects. We cluster standard errors at the client level and estimate the regressions over the sample period 2002-2011.

Columns (1) and (2) of Table 4 present the main results. Consistent with the logic outlined

\footnotetext{
${ }^{12}$ The Securities and Exchange Commission requires registrants with an aggregate worldwide market value of equity greater than $\$ 75$ million to file their financial statements earlier than smaller registrants.
} 
above, the coefficient on Merged Assets is negative and statistically significant in both column (1), which includes auditor fixed effects, and in column (2), which does not. Firms in industries that saw more action in mergers and acquisitions paid lower audit fees, all else equal.

As a further check on the validity of the merger measure as a supply shifter, we estimate a specification that, rather than including Merged Assets computed for the prior year, instead includes the ex post ratio of merged to total assets observed three years in the future. For these tests, the coefficients on Merged Assets in columns (3) and (4) are positive and insignificant. Thus merger activity leads price changes and not the reverse, increasing the likelihood that the results reflect the supply-shift story outlined above rather than a spurious connection between fees and merger activity due to other forces.

\subsubsection{Fit of Predicted Audit Fees}

Our random forest prediction specification yields fitted values that are highly correlated with actual audit fees within the sample. The Pearson product moment correlations between actual and predicted fees are as follows: Ernst \& Young, 0.977; Deloitte Touche, 0.959; KPMG, 0.971; PricewaterhouseCoopers, 0.970; all other auditors, 0.961. Figure A.1 in the Appendix presents plots of actual versus predicted log audit fees for our sample.

\section{Demand Estimation}

\subsection{Sample}

Our sample consists of SEC registrants with available data. We pull audit fee data from Audit Analytics, which provides fee data starting with the mandatory disclosure of audit fees in 2000 . We 
use Compustat to obtain accounting-based financials and the histories of auditor-client matches

prior to 2000 (we need this earlier match information to construct our measure of the extent of an existing auditor-client relationship). Finally, we identify client-level mergers and acquisitions using SDC Thomson data.

\subsection{Client Firms' Preferences over Auditors}

Panel A of Table 5 presents the results from estimating our benchmark demand model. These preference parameters form the basis for our estimates of clients' willingness to pay for audit services and willingness to substitute among audit firms. We estimate the preference functions separately by year over 2008-2010. To capture restrictions in the client's choice set, we remove audit firms that resigned from auditing the client in the prior three years. We identify such resignations from the Audit Analytics database. Such resignations arise from disagreements over fees, accounting practices, or issuances of going concern opinions. ${ }^{13}$

Several patterns emerge across the annual estimates. First, client firms' auditor choices are

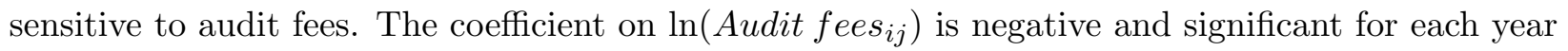
in the sample. We calculate and discuss the elasticities implied by these estimates below. ${ }^{14}$

Second, for each of the Big 4 audit firms, the interactions between the auditor fixed effects and client size are positive and significant each year, implying that larger clients have a stronger

\footnotetext{
${ }^{13}$ In addition, we estimated a separate set of demand parameters using firms in the top half of the distribution of size to address the possibility that the Big 4 audit firms selectively choose small clients because of litigation risk. Our demand estimates for this restricted sample are similar to those presented in Table 5. Moreover, the Sarbanes-Oxley Act prohibits audit firms from providing certain consulting services to their clients. Unfortunately, we are unable to observe restrictions on clients' choice sets due to such consulting relations with audit firms.

${ }^{14}$ While as noted we focus on the post-2001 period in order to exploit exogenous variation created by the implosion of Arthur Andersen, we found negative and significant coefficients on $\ln \left(\right.$ Audit fees $\left._{i j}\right)$ in untabulated tests for 2000 and 2001. We also estimated the model using fees predicted without including the Andersen implosion and merger supply-shifters. As theory predicts, the point estimates on predicted fees were on average more positive (that is, smaller in magnitude) than those in Table 5. The size of the differences were modest, however: the 2008 coefficient was essentially unchanged, while the 2009 and 2010 coefficients were -1.75 and -1.78 , respectively. Thus any price endogeneity due to unobservable demand shifts that existed in the market was relatively minor.
} 
preference for the Big 4. Similarly, client firms having a larger share of sales in foreign markets also have a preference for using a Big 4 auditor.

Third, having hired an auditor the previous year greatly affects the probability that a client firm hires them again, even after controlling for match-specific observables. The coefficients on the interactions of Big 4 dummies with 1(Not client $\left._{i j}\right)$ are negative and significant in every case. Thus the persistence in auditor choice discussed above reflects an unobserved match-specific attribute. On the other hand, the interactions with $\ln \left(\right.$ Years client $\left._{i j}\right)$ are generally positive but not often significant, implying that while having a current relationship is an important determinant of auditor choice, the duration of the history of this relationship is less important.

Panels B and C of Table 5 present annual mean estimates of client firms' own-price elasticitiesthe percentage change in the probability of choosing the auditor resulting from a one percent increase in audit fees. In general, as reflected in Panel B, the average estimated elasticities are in the neighborhood of -1.5 to -1.7 . An interesting contrast is observed, however, when we look at client firms' elasticities for their auditor in the prior year, as shown in Panel C. These estimates, which incorporate the effect on elasticities of our current-match variables (i.e., the interactions of auditor fixed effects with an indicator for the firm not being a client of the auditor and the number of years that the client firm has been working with its current auditor), reveal that client firms' choices are much less sensitive to changes in the fees of their current auditors. Elasticity estimates for the Big 4 are around -0.05 to -0.1 , an order of magnitude smaller than the average elasticities in Panel B. These differences reflect the powerful effect on choices of match-specific utility components within existing client-auditor pairs. As we will see below, the forced destruction of those matches, whether due to the exit of one of the Big 4 auditors or the imposition of mandatory auditor rotation, can destroy a considerable amount of client firms' consumer surplus. 


\subsection{Fit of the Model}

Our demand model fits the data quite well. Table 6 shows the correspondence between the client firms' predicted auditor choices (i.e., the auditor with the largest estimated mean utility for the client, $V_{i j}$ ) and their actual choices. Across each of the Big 4 audit firms, the model correctly predicts auditor choice for at least $91 \%$ of the clients. Moreover, for clients that chose a non-Big 4 audit firm the model based predictions are correct for over $96 \%$ of the clients.

We also have an interesting opportunity to test the model's predictive abilities by seeing how well it did in predicting which auditor former Andersen clients would choose in 2002, after Andersen's collapse forced them to choose a new auditor. Table 7 lays out the results. Panel A presents three sets of demand estimates for 2002: the first column shows estimates obtained using only clients of Arthur Andersen in 2001; the second column uses all client firms in 2002; the third column uses a sample of all client firms that were not Andersen clients in 2001. We use these parameters to generate predicted probabilities of auditor choice for Andersen clients in 2002. In general, these demand parameters are similar to those presented in Table 5. Importantly, the price coefficient is similar both in sign and magnitude to the baseline estimates. Panel B presents elasticity estimates for Andersen clients based on parameter estimates from the three models. As can be seen, these are similar to those presented in Panel B of Table 7.

In Panels A, B, and C of Table 8 we compare the actual auditor choices of Andersen clients in 2002 to the auditor with the highest predicted choice probability according to the demand estimates in Panel A of Table 7. In general, all three models provide better predictions than just chance. With one exception (Arthur Andersen clients in 2001 who hired PricewaterhouseCoopers in 2002, with estimates obtained using only the Andersen clients sample-i.e., the fourth row of Panel A), the auditor that the model predicts as most likely to be hired was in fact the auditor that the client 
firm actually hired. Importantly, even parameters estimated using only non-Andersen clients had predictive abilities for former Andersen client firms' choices.

\subsection{Alternative Specifications}

\subsubsection{Nested Logit}

An alternative model of audit firm choice is that clients first choose whether to use a non-Big 4 or Big 4 auditor and then, conditional on choosing a Big 4 auditor, choose which of the Big 4 to engage. To explore this possibility, we re-estimated our demand system using a nested logit specification, which incorporates this sequential choice structure explicitly. For these estimates, the substitution parameter between Big 4 and non-Big 4 is approximately $0.85-0.88$ and significantly different than the parameters that arise under the conditional logit model. ${ }^{15}$ However, the estimated marginal willingness to pay, $\alpha$, is similar to the baseline estimates presented in Panel A of Table 5. Further, there is no generally accepted method for generating error terms from a nested logit model (for discussions, see McFadden (1999), Herriges and Kling (1999), and Dagsvik and Karlstrom (2005)), a necessary step for our welfare calculations below. Therefore for the sake of parsimony we use the conditional logit model.

\subsubsection{Dollar Fees}

In our benchmark specification (1), client firms' choices of auditor are influenced by the logarithm of fees. We base this specification off of the observation that, institutionally, audit fee negotiations typically involve percentage changes in audit fees rather than absolute dollar changes. It also strikes as intuitive than an additional, say, $\$ 100,000$ increment to audit fees would foster a much larger

\footnotetext{
${ }^{15}$ The nested logit collapses to conditional logit if the substitution parameter equals one.
} 
response from a small client firm than from a very large one. To examine the sensitivity of the results to the log-linearity assumption, we also estimate a specification where fees enter in levels rather than logs. This specification imposes that a dollar of audit fees is equally important to large and small firms. The non-price preference parameter estimates from this dollar-price specification are similar to those presented in Table 5. The elasticity estimates are, however, about an eighth the magnitude of those based on the benchmark log price specification. This is what one would expect if, in reality, large firms were less sensitive than smaller firms were to a given dollar change in fees, as the model would attempt to explain this relative indifference by fitting a small coefficient to the fee level. The log price specification therefore appears to be better able to handle the heterogeneity in audit fees and client firms' responses to them that are driven by firm size differences.

\subsubsection{Competitor Overlap}

Aobdia (2012) documents the empirical regularity that large firms in concentrated industries are less likely to share auditors, presumably because of concerns about the transmission of proprietary information through the auditor. ${ }^{16}$ We therefore created a measure coded as the product of an indicator for whether firm i is within the top three firms in its industry as defined by four digit SIC, an indicator for whether auditor $\mathrm{j}$ audited at least one other top three firm in the industry, and a measure of the industry's concentration (the percentage of industry sales controlled by the top three firms). When we include this measure in our conditional logit specification, the coefficients are negative and therefore consistent with the findings of Aobdia (2012). The coefficients are not, however, statistically significant. This lack of significance appears to be driven by the fact that prior history of the match between the audit firm and client soaks up variation related to competitive overlaps. For example, when we estimate demand but exclude the history of firm-client match, the

\footnotetext{
${ }^{16}$ Asker and Ljungqvist (2010) find a similar effect for firm-bank matches.
} 
competitive overlap enters significantly for many of the years.

\section{Counterfactuals}

Having obtained estimates of client firms' preference parameters, we use them to address the two aforementioned policy-relevant issues: the effect of increased concentration among audit firms resulting from the exit of one of the Big 4 and the implementation of mandatory audit firm rotation at various tenures.

To estimate these counterfactuals, we use the methodology outlined by McFadden (1999). This involves calculating the expected change in consumer surplus for each audit client firm as the expected dollar transfer required to make that client indifferent between the unrestricted choice set of the status quo and the restricted choice set arising under the counterfactuals. We then sum these estimates of lost surplus across individual clients to find the expected total change in consumer surplus.

For example, suppose that under the status quo client i chooses the auditor $\mathrm{j}$ that yields maximized utility $\max _{j} U\left(\right.$ Audit $\left.f e e s_{i j}, x_{i j}, \epsilon_{i j}\right)$, and under the counterfactual firm i chooses auditor $\mathrm{m}$ from a restricted choice set that leads to maximized utility $\max _{m} U\left(\right.$ Audit fees $\left._{i m}, x_{i m}, \epsilon_{i m}\right)$. The change in consumer surplus, $C_{i j m}$, is the dollar transfer (or, equivalently, the reduction in audit fees) that would be required to equate the client's maximum utility under the restricted choice set with what it obtained under the unrestricted choice set:

$$
\max _{j} U\left(\text { Audit fees } i j, x_{i j}, \epsilon_{i j}\right)=\max _{m} U\left(\text { Audit fees } s_{i m}-C_{i j m}, x_{i m}, \epsilon_{i m}\right) .
$$

The total change in consumer surplus for the counterfactual is the sum of $C_{i j m}$ across client firms. 
Mechanically, to estimate $C_{i j m}$, for each firm i we draw a vector of type 1 extreme value error terms - one for each of the Big 4 auditors and one for the outside good. We then compute the utility client firm i would obtain from each auditor choice using equation (1) by combining the parameter estimates from Panel A of Table 5, the client firm and auditor characteristics observed in the data, and the error term draws. The auditor that delivers the largest utility of the five choices is then client firm i's simulated choice for that error draw. We next restrict the choice set for each client (i.e., depending on the counterfactual being estimated, remove one of the Big 4 auditors or remove the client's prior auditor based on tenure) and calculate the maximum utility that the client would receive under the restricted choice set. Then we solve for the $C_{i j m}$ that equates these two maximized utilities; given that dollar fees enter into utility in $\log$ form, $C_{i j m}$ is simply the exponent of the difference in maximized utilities between the unrestricted and restricted choice sets normalized by the estimated marginal willingness to pay. We repeat this procedure 1,000 times for each client firm, each time with new error vector, and then average the lost surplus values of $C_{i j m}$ from each simulation to compute $E\left[C_{i j m}\right]$. These values in hand, we aggregate these estimates across client firms to calculate the expected total change in consumer surplus in each counterfactual.

Computing the expected changes in consumer surplus as above using the observed audit fees in the data (or, more precisely, our estimates of audit fees given those observed in existing matches) effectively assumes that there is no supply-side response in the counterfactual scenarios. That is, it estimates the surplus lost by client firms if one of the Big 4 exits or if auditor rotation becomes mandatory while holding the fees charged by the remaining auditors fixed. In this sense, it estimates the pure demand-side effect of the counterfactuals. However, it seems likely that auditors might respond in these counterfactual worlds by changing their fees. (E.g., if one of the Big 4 exits, the resulting reduction in competition is likely to result in the remaining auditors charging higher fees within any given match.) Therefore we estimate two changes in expected surplus for each 
counterfactual scenario: a pure demand-side effect that holds auditors' price responses fixed, and a second that estimates and takes into account auditors' strategic price responses in the counterfactual scenario.

\subsection{Exit of a Big 4 Audit Firm}

The first counterfactual involves the exit of a Big 4 audit firm. We estimate the total expected changes in consumer surplus that would be caused by exit of each of the Big 4 auditors (in isolation, of course). We compute separate estimates using the demand parameters from each of the 2008, 2009, and 2010 samples to check the consistency of the results across subsamples.

Table 9, Panel A presents the estimated changes in consumer surplus when audit fees are held constant - that is, without allowing for any strategic price response from the remaining auditors. The estimated total changes in consumer surplus range from an approximately $\$ 1.3$ billion loss from the exit of Deloitte Touche to up to a $\$ 1.8$ billion loss for the disappearance of PricewaterhouseCoopers. These losses are substantial; for all of the Big 4, the estimated changes in consumer surplus range from $49 \%$ to $63 \%$ of each firm's total annual audit fees for our sample. The largest changes relative to total fees are for KPMG, 53-66\%, and the smallest are for PricewaterhouseCoopers, $49-57 \%$.

Panel B presents mean client-level changes in consumer surplus under the counterfactuals along with their correlations with client characteristics. As expected, the expected changes in consumer surplus are significantly larger for clients of an exiting audit firm than for non-clients. For clients the mean expected decrease in consumer surplus ranges from $\$ 1.3$ to $\$ 2.1$ million, while for non-clients the mean expected change in consumer surplus ranges from $\$ 14,000$ to $\$ 30,000$. With respect to correlations with firm characteristics, for clients of an exiting audit firm the expected changes in 
consumer surplus correlate with client size (correlation coefficients between 0.24 and 0.69 ), audit fees $(0.61-0.85)$, and tenure with the audit firm (0.17-0.31). For non-clients, the expected changes in consumer surplus are basically uncorrelated with client characteristics; that is, they are primarily driven by the error term, $\epsilon_{i j}$.

These estimates are subject to several caveats. One factor that could mitigate the size of the estimated losses is the possibility that audit teams from the exiting auditor move en masse with their clients to the remaining auditors. Presumably, some of the match-specific utility would move with the teams even if the audit firm disappears as a legal entity. ${ }^{17}$ On the other hand, there are multiple reasons why these estimates might understate the true loss of client firms' consumer surplus. For one, the estimates do not include lost surplus tied to non-audit services (such as consulting and tax services) audit firms might also provide to their clients. Additionally, the estimates exclude any surplus lost by an exiting auditor's domestic private or international clients. Finally, these estimates are calculated based on the disappearance of a Big 4 audit firm from clients' choice sets for only one year. If the persistence of auditor-client matches is solely due to switching costs, then our single-year estimates should capture most of the present value of the change in consumer surplus, as once the switch is forced by the counterfactual Big 4 exit, no further losses of this type would be induced. However, given any persistence in auditor-client matches due instead to unobserved heterogeneity and match-specific capital, the estimates reflect only the first year's loss of the surplus created by these match-specific components; the permanent demise of a Big 4 audit firm may impose similar losses for years into the future.

\footnotetext{
${ }^{17}$ Consistent with this possibility, Blouin, Grein, and Rountree (2007) find that some Arthur Andersen clients followed their Andersen audit teams to the remaining Big 4 auditors.
} 


\subsection{Introduction of Mandatory Audit Firm Rotation}

The second counterfactual scenario involves the implementation of mandatory audit firm rotation. To estimate the expected change in consumer surplus in this case, we calculate the dollar transfer required to make clients indifferent to the removal of their current auditor from their choice set once the client-auditor match has lasted beyond the statutory maximum allowed. We compute separate estimates for different possible statutory maximum tenures, running from four through ten years. We also again compute estimates using each of the sets of estimated demand parameters from 2008, 2009, and 2010.

Table 10, Panel A presents these expected total changes in consumer surplus. They are significantly larger than expected changes that arise from the disappearance of one of the Big 4, ranging from $\$ 2.4-2.8$ billion if rotation is mandatory after ten years to $\$ 4.3-5.1$ billion if rotation is mandatory after four years. (The estimated lost surplus is larger for shorter horizons because a greater number of matches are affected.) The observed persistence of auditor-client matches results in mandatory audit firm rotation producing larger changes in consumer surplus because the former affects a larger proportion of clients.

Panel B contains mean client-level changes in consumer surplus under the mandatory audit firm rotation counterfactuals and their correlations with client characteristics. Similarly to the aggregate estimates presented in Panel A, the client-level means decrease as the horizon increases, as more client firms are left unaffected by the mandate. If rotation is mandatory after four years, the mean expected change in consumer surplus ranges from $\$ 800,000$ to $\$ 1$ million depending upon the year the mandate would have been imposed. If rotation is mandatory after ten years, the mean expected change in consumer surplus ranges from about $\$ 450,000$ to $\$ 550,000$. The expected changes in surplus also correlate with client characteristics, with the highest correlations for audit 
fees $(0.50-0.75)$, followed by tenure with the audit firm (0.34-0.57), and then client size $(0.14-0.47)$.

Note that even though no auditors exit the market in this counterfactual scenario, mandatory auditor rotation implies an increase in market concentration just as the Big 4 exit scenario does. This is because the auditor that is forced out due to rotation is necessarily removed from its formerly matched client firm's choice set. If the remaining eligible auditors recognize they now face less competition when negotiating over audit fees with the client firm, this may lead to higher fees. The lost surplus estimates in Table 10 do not incorporate any such pricing response, focusing only on the demand-side consequences of mandatory rotation. Below, however, as we also do with the Big 4 exit counterfactual, we estimate the expected size of the supply-side audit fee (i.e., pricing) responses of the remaining competing auditors and compute the consequences of this response for client firms' consumer surplus.

An alternative interpretation of these estimates is that they represent what managers (as opposed to shareholders) are willing to pay in order to avoid switching auditors and the estimates therefore represent agency costs. Under this interpretation, long tenures lead to a loss of auditor independence that managers exploit for their private benefit. Prior literature, however, does not provide support for the idea that auditor independence decreases over longer tenures. In fact, several studies find that audit failures are more likely to occur during the early years of tenure (e.g., Carcello and Nagy (2004) and Geiger and Raghunandan (2002), and others find that audit quality appears to increase over auditor tenure (e.g., Chen, Lin, and Lin (2008), Ghosh and Moon (2005), and Myers, Myers, and Omer (2003)). We therefore interpret these estimates as representing a change in consumer surplus. Nevertheless, as we noted above, there may also be social benefits from imposing mandatory rotation. Our estimates serve to quantify the costs such mandates impose on client firms - costs that any social benefits would have to be weighed against in evaluating 
mandatory rotation policies.

\subsection{Supply Side Price Response}

As we have discussed, the counterfactual changes in surplus computed above hold audit fees fixed, isolating the surplus changes due to demand-side effects only. In this section, we estimate what the supply-side responses might be under the counterfactual scenarios and quantify their additional impact on client firms' expected surplus.

To estimate the supply response, we first note that both counterfactual scenarios involve reductions in competition. In standard oligopoly models, reductions in competition-resulting from the actual exit of one of the market competitors in one counterfactual and the de facto exit of a client firm's former auditor (at least for that client firm) in the other-lead to higher prices. Our estimate of the counterfactual audit fee changes due to the supply response works off this logic. Specifically, we estimate in our sample how changes in auditor competition for clients within an industry relates to average audit fee changes in that industry.

A typical concern when estimating such relationships is that market structure and prices are both endogenous outcomes, making causal inference difficult. However, we are fortunate in that we have (and indeed have already used for demand estimation purposes above) an exogenous change in competition at the industry level, the collapse of Arthur Andersen. Thus we can identify the causal relationship between competition and fees by estimating the semi-elasticity of audit fees in 2002 with respect to the percent share of industry total assets audited by Arthur Andersen in 2001 based on three-digit SIC. (This regression is presented in Table A.3.) ${ }^{18}$ We estimate this

\footnotetext{
${ }^{18}$ We estimate this effect for the period prior to the implementation of mandatory internal control audits under the Sarbanes-Oxley Act. Hence, variation in fees represents changes in industry concentration as opposed to changes in demand due to increased regulatory requirements. For a discussion, see Feldman (2006) and Kohlbeck, Mayhew, Murphy, and Wilkins (2008).
} 
semi-elasticity using ordinary least squares and controlling for the standard audit fee determinants. This semi-elasticity is that audit fees rise $0.15 \%$ for each one percentage point of total industry assets that had been audited by Arthur Andersen before its collapse.

Table 11 presents estimates of the annual increase in total audit fees that would occur if a Big 4 audit firm were to disappear. These estimates range from $\$ 335$ million for the disappearance of KPMG in 2010 to $\$ 533$ million for the disappearance of PricewaterhouseCoopers in 2008. Table 12 presents estimates of annual increases in total audit fees that would occur under each of the mandatory audit firm rotation horizons. These estimated annual increases range from $\$ 772$ million for the implementation of ten year rotation in 2010 to $\$ 1.34$ billion for four year rotation in 2008 . The estimated annual increases in fees are over twice as large under this scenario as in the Big 4 exit case, which is to be expected given that mandatory audit firm rotation would affect a larger number of client firms.

When combined with the estimated demand-side losses in Table 9, and Table 10, the supply response implies estimated initial surplus losses among client firms totalling in the neighborhood of $\$ 1.6-2.3$ billion in the case of exit of one of the Big 4 auditors and around $\$ 3.1-3.5$ billion (ten-year maximum tenure) or $\$ 5.6-6.4$ billion (four-year maximum tenure) in the case of mandatory auditor rotation.

New entry into the market would determine the extent that such annual increases in total audit fees persist into the future. Absent new entry, these increases in annual audit fees could persist indefinitely. The limited entry response subsequent to the collapse of Arthur Andersen, not to mention the revealed reluctance among policymakers to force any further consolidation through legal action, suggests that such increases would likely be quite persistent. 


\section{Conclusion}

The audit industry receives considerable policy attention for several reasons. Using estimates of publicly listed firms' demand for audit services, we have evaluated the consequences for client firms of two important policy-related scenarios: further concentration of the audit industry due to exit of one of the Big 4 audit firms, and the imposition of mandatory auditor rotation.

The estimated parameters of our model, which fit the data quite well, imply that both scenarios would impose substantial costs. The direct impacts on client firms' choice sets along imply, surplus losses of about $\$ 1.5$ billion for exit of one of the Big 4 and $\$ 2.5-5.0$ billion for mandatory auditor rotation (shorter mandated maximum tenures create larger losses of surplus). Factoring in the expected supply responses of the remaining auditors-increases in fees due to decreased competitionraises these figure by another 25 percent. Moreover, there are several reasons why these estimated losses are likely to be conservative, including that these figures are for initial one-year surplus losses, while in reality both the loss of choice and increase in fees from less competition are likely to be persistent.

While we have used our framework to address two of the more salient policy questions in the audit industry, we believe our empirical framework can be applied to other sets of economic questions about the industry, and purchased business services more broadly. Furthermore, we see potential gains from analyzing the audit industry in a more explicit economic framework that separates demand from supply effects to better understand the sources and consequences of shifts in the industry's market conditions. 


\section{REFERENCES}

Aobdia, D. (2012). Proprietary information spillovers and auditor choice. Unpublished working paper, UCLA.

Asker, J. and A. Ljungqvist (2010). Competition and the structure of vertical relationships in captial markets. Journal of Political Economy 118(3), 599-647.

Ball, R. (2001). Infrastructure Requirements for an Economicallly Efficient System of Public Financial Reporting and Disclsoure. Brookings-Wharton Papers on Financial Services 1, 127169.

Black, B. (2000-2001). The Legal and Institutional Preconditions for Strong Securities Markets. UCLA Law Review 48, 781-856.

Blouin, J., B. Grein, and B. Rountree (2007). An analysis of forced auditor change: The case of former Arthur Andersen clients. The Accounting Review 82(3), 621-650.

Cahan, S., W. Zhang, and D. Veenman (2011). Did the Waste Management Audit Failures Signal Lower Firm-Wide Audit Quality at Arthur Andersen? Contemporary Accounting Research 28(3), 859-891.

Carcello, J. and A. Nagy (2004). Audit Firm Tenure and Fraudualent Financial Reporting. Auditing: A Journal of Practice and Theory 23(2), 55-69.

Casterella, J., J. Francis, B. Lewis, and P. Walker (2004). Auditor Industry Specialization, Client Bargaining Power, and Audit Pricing. Auditing: A Journal of Practice and Theory 23(1), $123-140$.

Chen, C., C. Lin, and Y. Lin (2008). Audit Partner Tenure, Audit Firm Tenure, and Discretionary Accruals: Does Long Auditor Tenure Impair Earnings Quality? Contemporary Accounting Research 25(2), 415-445. 
Cohn, M. (2013, June 20). House Committee Passes Bill Preventing PCAOB from Imposing Audit Firm Rotation. Accounting Today 1.

Craswell, A., J. Francis, and S. Taylor (1995). Auditor brand name reputations and industry specializations. Journal of Accounting and Economics 20, 297-322.

Dagsvik, J. and A. Karlstrom (2005). Compensating variation and hicksian choice probabilities in random utility models that are nonlinear in income. Review of Economic Studies 72(1), $57-76$.

Doogar, R. and R. Easley (1998). Concentration without differentiation: A new look at the determinants of audit market concentration. Journal of Accounting and Economics 25, 235253.

Erdem, T., M. Keane, and B. Sun (1999). Missing price and coupon availability data in scanner panels: Correcting for self-selection bias in choice model parameters. Journal of Econometrics 89, 177-196.

Ettredge, M., S. Kwon, and C. Lim (2009). Client, Industry, and Country Factors Affecting Choice of Big N Industry Expert Auditors. Journal of Accounting, Auditing, and Finance 24, $433-476$.

Feldman, E. (2006). A Basic Quantification of the Competitive Implications of the Demise of Arthur Andersen. Review of Industrial Organization 29, 193-212.

Geiger, M. and K. Raghunandan (2002). Auditor Tenure and Audit Report Failures. Auditing: A Journal of Practice and Theory 21(1), 67-78.

Ghosh, A. and D. Moon (2005). Auditor tenure and perceptions of audit quality. The Accounting Review 80(2), 585-612.

Hastie, T., R. Tibshirani, and J. Friedman (2009). The Elements of Statistical Learning (2nd 
ed.). New York, NY: Springer.

Hay, R., W. Knechel, and N. Wong (2006). Audit Fees: A Meta-analysis of the Effect of Supply and Demand Attributes. Contemporary Accounting Research 23(1), 141-191.

Herriges, J. and C. Kling (1999). Nonlinear Income Effects in Random Utility Models. Review of Economics and Statistics 81(1), 62-72.

Hogan, C. and D. Jeter (1999). Industry Specialization by Auditors. Auditing: A Journal of Practice and Theory 18(1), 1-17.

Johnson, C. (2010, January 4). Charge Against KPMG Dropped. Washington Post.

Kohlbeck, M., B. Mayhew, P. Murphy, and M. Wilkins (2008). Competition for andersen's clients. Contemporary Accounting Research 25(4), 1099-1136.

Lennox, C., J. Francis, and Z. Wang (2012). Selection Models in Accounting Research. The Accounting Review 87(2), 589-616.

McFadden, D. (1999). Computing willingess to pay in random utility models. Trade, Theory, and Econometrics: Essays in honour of John S. Chipman 15, 253-274.

Myers, J., L. Myers, and T. Omer (2003). Exploring the Term of the Auditor-Client Relationship and the Quality of Earnings: A Case for Mandatory Auditor Rotation. The Accounting Review 78(3), 799-799.

Petrin, A. (2002). Quantifying the benefits of new products: The case of the minivan. Journal of Political Economy 119(4), 705-729.

Public Accounting Report (2011, January 31). E\&Y, Deloitte Face New Challenges in Lehman and Bear Stearns Cases.

Sirois, L.-P. and D. Simunic (2013). Auditor Size and Audit Quality Revisited: The Importance of Audit Technology. Unpublished working paper, University of British Columbia. 
Train, K. (2009). Discrete Choice Methods with Simulation. New York, NY: Cambridge University Press.

Tysiac, K. (2012). PCAOB panelists say mandatory firm rotation could be harmful, helpful. Journal of Accountancy 213(4).

Valukas, A. (2010). In re Lehman Bros. Holdings. Technical Report no. 08-13555, ECF No. 7530, Jenner \& Block LLP, Bankr. SDNY.

Velte, P. and M. Stiglbauer (2012). Audit Market Concentration and Its Influence on Audit Quality. International Business Research 5(11), 146-161.

Watts, R. and J. Zimmerman (1983). Agency Problems, Auditing, and the Theory of the Firm: Some Evidence. Journal of Law and Economics 26(3), 613-633.

Willenborg, M. (1999). Empirical analysis of the economic demand for auditing in the initial public offerings market. Journal of Accounting Research 37(1), 225-238. 
Table 1: Market shares

This table presents annual market shares of SEC registrant audits for the Big 4 and non-Big 4 auditors as well as the mean Herfindahl Index of those shares within three-digit SIC industries. Panel A calculates market shares and Herfindahl Indices based on audit fees and Panel B calculates market shares and Herfindahl Indices based on number of clients. Audit fees and clients are taken from the Audit Analytics database.

Panel A: Market shares based on audit fees

\begin{tabular}{ccccccc}
\hline & E\&Y & Deloitte & KPMG & PwC & non-Big 4 & HHI SIC3 \\
\hline 2002 & $22.50 \%$ & $18.88 \%$ & $23.92 \%$ & $31.55 \%$ & $3.15 \%$ & 4,957 \\
2003 & $23.15 \%$ & $19.78 \%$ & $21.71 \%$ & $32.11 \%$ & $3.25 \%$ & 4,955 \\
2004 & $22.40 \%$ & $20.71 \%$ & $21.41 \%$ & $32.17 \%$ & $3.31 \%$ & 5,157 \\
2005 & $23.64 \%$ & $21.44 \%$ & $20.38 \%$ & $29.93 \%$ & $4.62 \%$ & 5,111 \\
2006 & $24.22 \%$ & $20.96 \%$ & $20.19 \%$ & $29.41 \%$ & $5.22 \%$ & 5,133 \\
2007 & $25.24 \%$ & $22.17 \%$ & $19.52 \%$ & $27.04 \%$ & $6.04 \%$ & 4,979 \\
2008 & $24.21 \%$ & $22.32 \%$ & $19.44 \%$ & $28.16 \%$ & $5.85 \%$ & 4,968 \\
2009 & $25.06 \%$ & $21.74 \%$ & $18.71 \%$ & $28.89 \%$ & $5.59 \%$ & 5,070 \\
2010 & $25.21 \%$ & $21.35 \%$ & $18.93 \%$ & $29.23 \%$ & $5.28 \%$ & 5,050 \\
\hline
\end{tabular}

Panel B: Market shares based on number of clients

\begin{tabular}{ccccccc}
\hline & E\&Y & Deloitte & KPMG & PwC & non-Big 4 & HHI SIC3 \\
\hline 2002 & $23.86 \%$ & $16.71 \%$ & $19.93 \%$ & $22.15 \%$ & $17.35 \%$ & 3,832 \\
2003 & $23.16 \%$ & $16.39 \%$ & $19.16 \%$ & $21.65 \%$ & $19.64 \%$ & 3,785 \\
2004 & $21.45 \%$ & $15.97 \%$ & $18.32 \%$ & $20.42 \%$ & $23.84 \%$ & 4,034 \\
2005 & $21.03 \%$ & $15.59 \%$ & $16.49 \%$ & $18.04 \%$ & $28.86 \%$ & 4,096 \\
2006 & $20.85 \%$ & $14.86 \%$ & $15.61 \%$ & $16.64 \%$ & $32.04 \%$ & 4,195 \\
2007 & $20.83 \%$ & $14.53 \%$ & $14.51 \%$ & $15.75 \%$ & $34.38 \%$ & 4,114 \\
2008 & $20.78 \%$ & $14.44 \%$ & $14.37 \%$ & $15.77 \%$ & $34.63 \%$ & 4,191 \\
2009 & $20.82 \%$ & $14.65 \%$ & $14.59 \%$ & $15.58 \%$ & $34.35 \%$ & 4,260 \\
2010 & $20.95 \%$ & $14.94 \%$ & $15.16 \%$ & $16.03 \%$ & $32.93 \%$ & 4,262 \\
\hline
\end{tabular}


Table 2: Auditor switches

This table presents transition matrices of client switches between audit firms over the period 20082010 .

\begin{tabular}{|c|c|c|c|c|c|c|c|}
\hline & & \multicolumn{6}{|c|}{ Year $t+1$} \\
\hline & & $\mathrm{E} \& \mathrm{Y}$ & Deloitte & KPMG & $\mathrm{PwC}$ & non-Big 4 & Total \\
\hline \multirow{11}{*}{ 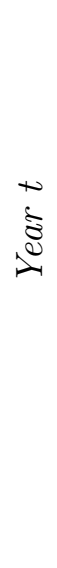 } & E\&Y & 2,986 & 18 & 24 & 20 & 36 & 3,084 \\
\hline & & $96.8 \%$ & $0.6 \%$ & $0.8 \%$ & $0.6 \%$ & $1.2 \%$ & \\
\hline & Deloitte & 25 & 2,076 & 12 & 22 & 42 & 2,177 \\
\hline & & $1.1 \%$ & $95.4 \%$ & $0.6 \%$ & $1.0 \%$ & $1.9 \%$ & \\
\hline & KPMG & 25 & 9 & 2,086 & 16 & 34 & 2,170 \\
\hline & & $1.2 \%$ & $0.4 \%$ & $96.1 \%$ & $0.7 \%$ & $1.6 \%$ & \\
\hline & $\mathrm{PwC}$ & 17 & 21 & 13 & 2,277 & 23 & 2,351 \\
\hline & & $0.7 \%$ & $0.9 \%$ & $0.6 \%$ & $96.9 \%$ & $1.0 \%$ & \\
\hline & non-Big 4 & 26 & 17 & 35 & 23 & 4,725 & 4,826 \\
\hline & & $0.5 \%$ & $0.4 \%$ & $0.7 \%$ & $0.5 \%$ & $97.9 \%$ & \\
\hline & Total & 3,079 & 2,141 & 2,170 & 2,358 & 4,860 & 14,608 \\
\hline
\end{tabular}


Table 3: Validation of Arthur Andersen supply shifter

This table presents regressions that validate the use of the disappearance of Arthur Andersen as a supply shifter. The dependent variable in all of the regressions is the log growth in audit fees from 2001 to the relevant year. The supply shifter is Arthur Andersen's share of the industry in 2001, with industries based on three-digit SIC codes. Standard errors are in parentheses and clustered at the three-digit SIC level. Panel A presents results for all firms and Panel B presents results for firms that were not clients of Arthur Andersen in 2001.

Panel A: All firms

\begin{tabular}{lccc}
\hline & 2008 & 2009 & 2010 \\
\hline \multirow{2}{*}{ Andersen's Industry Share in 2001 } & $0.269^{*}$ & $0.255^{* *}$ & $0.228^{* *}$ \\
& $(0.138)$ & $(0.114)$ & $(0.102)$ \\
Andersen Client in 2001 & $0.346^{* * *}$ & $0.283^{* * *}$ & $0.260^{* * *}$ \\
& $(0.034)$ & $(0.035)$ & $(0.042)$ \\
E\&Y Client in 2001 & $0.334^{* * *}$ & $0.257^{* * *}$ & $0.234^{* * *}$ \\
& $(0.034)$ & $(0.034)$ & $(0.036)$ \\
Deloitte Client in 2001 & $0.288^{* * *}$ & $0.208^{* * *}$ & $0.197^{* * *}$ \\
& $(0.037)$ & $(0.036)$ & $(0.041)$ \\
KPMG Client in 2001 & $0.293^{* * *}$ & $0.196^{* * *}$ & $0.218^{* * *}$ \\
& $(0.043)$ & $(0.047)$ & $(0.054)$ \\
PwC Client in 2001 & $0.346^{* * *}$ & $0.271^{* * *}$ & $0.255^{* * *}$ \\
Change in Ln(Assets) & $(0.035)$ & $(0.033)$ & $(0.037)$ \\
& $0.386^{* * *}$ & $0.396^{* * *}$ & $0.409^{* * *}$ \\
Constant & $(0.026)$ & $(0.021)$ & $(0.018)$ \\
& $0.776^{* * *}$ & $0.792^{* * *}$ & $0.767^{* * *}$ \\
& $(0.046)$ & $(0.035)$ & $(0.026)$ \\
Observations & & & \\
Adjusted $R^{2}$ & 2,806 & 2,612 & 2,399 \\
*** p<0.01,** p<0.05 * p $^{*}<0.1$ & 0.249 & 0.273 & 0.298 \\
\hline
\end{tabular}


Panel B: Not an Arthur Andersen client in 2001

\begin{tabular}{|c|c|c|c|}
\hline & 2008 & 2009 & 2010 \\
\hline Andersen's Industry Share in 2001 & $\begin{array}{c}0.324^{* *} \\
(0.147)\end{array}$ & $\begin{array}{c}0.309^{* * *} \\
(0.118)\end{array}$ & $\begin{array}{c}0.275^{* * *} \\
(0.103)\end{array}$ \\
\hline Deloitte Client in 2001 & $\begin{array}{c}0.287^{* * *} \\
(0.037)\end{array}$ & $\begin{array}{c}0.207^{* * *} \\
(0.036)\end{array}$ & $\begin{array}{c}0.197^{* * *} \\
(0.041)\end{array}$ \\
\hline KPMG Client in 2001 & $\begin{array}{c}0.293^{* * *} \\
(0.044)\end{array}$ & $\begin{array}{c}0.196^{* * *} \\
(0.047)\end{array}$ & $\begin{array}{c}0.218^{* * *} \\
(0.054)\end{array}$ \\
\hline PwC Client in 2001 & $\begin{array}{c}0.345^{* * *} \\
(0.034)\end{array}$ & $\begin{array}{c}0.271^{* * *} \\
(0.033)\end{array}$ & $\begin{array}{c}0.254^{* * *} \\
(0.037)\end{array}$ \\
\hline Change in $\operatorname{Ln}$ (Assets) & $\begin{array}{c}0.389^{* * *} \\
(0.027)\end{array}$ & $\begin{array}{c}0.403^{* * *} \\
(0.023)\end{array}$ & $\begin{array}{c}0.417^{* * *} \\
(0.020)\end{array}$ \\
\hline Constant & $\begin{array}{c}0.767^{* * *} \\
(0.045)\end{array}$ & $\begin{array}{c}0.781^{* * *} \\
(0.033)\end{array}$ & $\begin{array}{c}0.756^{* * *} \\
(0.027)\end{array}$ \\
\hline Observations & 2,332 & 2,169 & 1,987 \\
\hline Adjusted $R^{2}$ & 0.250 & 0.279 & 0.303 \\
\hline
\end{tabular}

*** $\mathrm{p}<0.01,{ }^{* *} \mathrm{p}<0.05,{ }^{*} \mathrm{p}<0.1$ 
Table 4: Client mergers as a supply shifter

This table presents regressions that validate the use of client mergers as a supply shifter. The dependent variable in all of the regressions is the natural logarithm of audit fees. The supply shifter is the ratio of merged to total assets in an industry based on the three-digit SIC codes for the prior year. Columns (1) and (2) present regressions in which the shifter is for the prior year. Columns (3) and (4) validate the shifter by setting it forward three years. Standard errors are in parentheses and clustered at the firm-level.

\begin{tabular}{|c|c|c|c|c|}
\hline & (1) & $(2)$ & $(3)$ & (4) \\
\hline Merged to Total Assets & $\begin{array}{c}-0.093^{* *} \\
(0.039)\end{array}$ & $\begin{array}{c}-0.094^{* *} \\
(0.039)\end{array}$ & & \\
\hline Merged to Total Assets +3 Years & & & $\begin{array}{l}-0.024 \\
(0.039)\end{array}$ & $\begin{array}{l}-0.019 \\
(0.040)\end{array}$ \\
\hline $\operatorname{Ln}$ (Assets) & $\begin{array}{c}0.405^{* * *} \\
(0.008)\end{array}$ & $\begin{array}{c}0.428^{* * *} \\
(0.008)\end{array}$ & $\begin{array}{c}0.400^{* * *} \\
(0.008)\end{array}$ & $\begin{array}{c}0.424^{* * *} \\
(0.009)\end{array}$ \\
\hline Receivables to Assets & $\begin{array}{c}0.251^{* * *} \\
(0.050)\end{array}$ & $\begin{array}{c}0.241^{* * *} \\
(0.051)\end{array}$ & $\begin{array}{c}0.253^{* * *} \\
(0.055)\end{array}$ & $\begin{array}{c}0.242^{* * *} \\
(0.057)\end{array}$ \\
\hline Inventory to Assets & $\begin{array}{c}0.344^{* * *} \\
(0.072)\end{array}$ & $\begin{array}{c}0.337^{* * *} \\
(0.075)\end{array}$ & $\begin{array}{c}0.326^{* * *} \\
(0.079)\end{array}$ & $\begin{array}{c}0.321^{* * *} \\
(0.082)\end{array}$ \\
\hline Return on Assets & $\begin{array}{c}-0.263^{* * *} \\
(0.019)\end{array}$ & $\begin{array}{c}-0.283^{* * *} \\
(0.019)\end{array}$ & $\begin{array}{c}-0.271^{* * *} \\
(0.020)\end{array}$ & $\begin{array}{c}-0.292^{* * *} \\
(0.021)\end{array}$ \\
\hline Loss & $\begin{array}{c}0.036^{* * *} \\
(0.006)\end{array}$ & $\begin{array}{c}0.033^{* * *} \\
(0.006)\end{array}$ & $\begin{array}{c}0.036^{* * *} \\
(0.007)\end{array}$ & $\begin{array}{c}0.033^{* * *} \\
(0.007)\end{array}$ \\
\hline Percent Foreign Sales & $\begin{array}{c}0.072^{* * *} \\
(0.016)\end{array}$ & $\begin{array}{c}0.075^{* * *} \\
(0.017)\end{array}$ & $\begin{array}{c}0.070^{* * *} \\
(0.018)\end{array}$ & $\begin{array}{c}0.071^{* * *} \\
(0.019)\end{array}$ \\
\hline Ln(Segments) & $\begin{array}{c}0.023^{* * *} \\
(0.006)\end{array}$ & $\begin{array}{c}0.025^{* * *} \\
(0.007)\end{array}$ & $\begin{array}{c}0.020^{* * *} \\
(0.007)\end{array}$ & $\begin{array}{c}0.022^{* * *} \\
(0.007)\end{array}$ \\
\hline Accelerated Filer & $\begin{array}{c}-0.049^{* * *} \\
(0.008)\end{array}$ & $\begin{array}{c}-0.054^{* * *} \\
(0.008)\end{array}$ & $\begin{array}{c}-0.057^{* * *} \\
(0.009)\end{array}$ & $\begin{array}{c}-0.064^{* * *} \\
(0.009)\end{array}$ \\
\hline Going Concern Opinion & $\begin{array}{c}0.048^{* * *} \\
(0.013)\end{array}$ & $\begin{array}{c}0.057^{* * *} \\
(0.013)\end{array}$ & $\begin{array}{c}0.055^{* * *} \\
(0.014)\end{array}$ & $\begin{array}{c}0.064^{* * *} \\
(0.014)\end{array}$ \\
\hline Constant & $\begin{array}{c}9.010^{* * *} \\
(0.429)\end{array}$ & $\begin{array}{c}8.919^{* * *} \\
(0.439)\end{array}$ & $\begin{array}{c}9.158^{* * *} \\
(0.328)\end{array}$ & $\begin{array}{c}9.054^{* * *} \\
(0.332)\end{array}$ \\
\hline Observations & 69,280 & 69,280 & 59,123 & 59,123 \\
\hline Adjusted $R^{2}$ & 0.641 & 0.628 & 0.647 & 0.635 \\
\hline Firm fixed effects & Yes & Yes & Yes & Yes \\
\hline Auditor fixed effects & Yes & No & Yes & No \\
\hline Year fixed effects & Yes & Yes & Yes & Yes \\
\hline Industry fixed effects & Yes & Yes & Yes & Yes \\
\hline Number of clients & 10,525 & 10,525 & 10,162 & 10,162 \\
\hline
\end{tabular}


Table 5: Demand estimation

This table presents estimates of demand and price elasticity for SEC registrants over the period 2008-2010. Panel A presents annual estimates of the demand for the Big 4 audit firms. The regressions are estimated using conditional logit with the outside good being the non-Big 4 audit firms. $\mathrm{Ln}$ (Predicted Fees) is the natural logarithm of predicted fees for each of the Big 4 audit firms. E\&Y, Deloitte, KPMG, and PwC are brand fixed effects for each of the Big 4 audit firms. Ln(Assets) is the natural logarithm of the client's total assets, $\operatorname{Ln}$ (Segments) is the natural logarithm of the client's industrial segments, Foreign Sales is the percentage of the clients sales generated outside of the US, Debt is the ratio of short- and long-term debt to total assets for the client, ROA is the client's return on assets, Inventory + Receivables is the client's ratio of inventory and receivables to total assets, and Payables is the ratio of the client's account payables to total assets. Ln(Years Client) is the number of years that the SEC registrant has been a client of the audit firm, and Not Prior Client is an indicator variable for whether the SEC registrant was not a client of the audit firm in the prior three years. Not tabulated are interactions between the brand fixed effects and indicators for the Fama-French ten industries. Data on client characteristics are taken from Compustat. Panel B presents annual mean price elasticity estimates by audit firm for all clients. Panel C presents annual mean price elasticity estimates by audit firm conditional on being a client of the audit firm in the prior year. 
Panel A: Demand estimates

\begin{tabular}{|c|c|c|c|}
\hline & 2008 & 2009 & 2010 \\
\hline Ln(Predicted Fees) & $\begin{array}{l}-2.052 * * * \\
(0.138)\end{array}$ & $\begin{array}{c}-1.935^{* * *} \\
(0.147)\end{array}$ & $\begin{array}{c}-1.941^{* * * *} \\
(0.152)\end{array}$ \\
\hline $\mathrm{E} \& \mathrm{Y}$ & $\begin{array}{c}2.498^{* * * *} \\
(0.602)\end{array}$ & $\begin{array}{c}1.738^{* * *} \\
(0.661)\end{array}$ & $\begin{array}{c}2.913^{* * *} \\
(0.752)\end{array}$ \\
\hline Deloitte & $\begin{array}{c}1.797^{* * *} \\
(0.695)\end{array}$ & $\begin{array}{c}2.894 * * * \\
(0.724)\end{array}$ & $\begin{array}{c}1.829^{* * *} \\
(0.703)\end{array}$ \\
\hline KPMG & $\begin{array}{l}1.163^{*} \\
(0.689)\end{array}$ & $\begin{array}{l}1.990^{* * *} \\
(0.704)\end{array}$ & $\begin{array}{l}2.478^{* * *} \\
(0.777)\end{array}$ \\
\hline $\mathrm{PwC}$ & $\begin{array}{c}2.084^{* * *} \\
(0.768)\end{array}$ & $\begin{array}{c}0.555 \\
(0.745)\end{array}$ & $\begin{array}{c}2.686^{* * *} * \\
(0.889)\end{array}$ \\
\hline $\mathrm{E} \& \mathrm{Y} * \operatorname{Ln}($ Assets $)$ & $\begin{array}{c}0.498^{* * * *} \\
(0.062)\end{array}$ & $\begin{array}{c}0.570 * * * \\
(0.073)\end{array}$ & $\begin{array}{c}0.536^{* * *} \\
(0.071)\end{array}$ \\
\hline Deloitte ${ }^{*} \operatorname{Ln}($ Assets $)$ & $\begin{array}{c}0.495^{* * *} \\
(0.069)\end{array}$ & $\begin{array}{c}0.428 * * * \\
(0.071)\end{array}$ & $\begin{array}{c}0.484^{* * *} \\
(0.070)\end{array}$ \\
\hline KPMG * Ln(Assets) & $\begin{array}{c}0.551 * * * \\
(0.071)\end{array}$ & $\begin{array}{c}0.392 * * * \\
(0.075)\end{array}$ & $\begin{array}{c}0.416 * * * \\
(0.074)\end{array}$ \\
\hline PwC * Ln(Assets) & $\begin{array}{c}0.504 * * * \\
(0.076)\end{array}$ & $\begin{array}{c}0.559 * * * \\
(0.078)\end{array}$ & $\begin{array}{c}0.572^{* * *} \\
(0.076)\end{array}$ \\
\hline $\mathrm{E} \& \mathrm{Y} * \operatorname{Ln}($ Segments $)$ & $\begin{array}{c}-0.259^{* *} \\
(0.128)\end{array}$ & $\begin{array}{l}-0.179 \\
(0.149)\end{array}$ & $\begin{array}{l}-0.076 \\
(0.159)\end{array}$ \\
\hline Deloitte $*$ Ln(Segments) & $\begin{array}{l}0.132 \\
(0.144)\end{array}$ & $\begin{array}{c}-0.308^{* *} \\
(0.149)\end{array}$ & $\begin{array}{l}-0.058 \\
(0.161)\end{array}$ \\
\hline KPMG * Ln(Segments) & $\begin{array}{l}-0.092 \\
(0.152)\end{array}$ & $\begin{array}{l}-0.184 \\
(0.166)\end{array}$ & $\begin{array}{c}0.261 \\
(0.164)\end{array}$ \\
\hline PwC $* \operatorname{Ln}($ Segments) & $\begin{array}{l}-0.076 \\
(0.154)\end{array}$ & $\begin{array}{l}0.198 \\
(0.154)\end{array}$ & $\begin{array}{l}-0.259 \\
(0.169)\end{array}$ \\
\hline E\&Y * Foreign Sales & $\begin{array}{c}0.578^{* *} \\
(0.238)\end{array}$ & $\begin{array}{c}0.538^{* *} \\
(0.274)\end{array}$ & $\begin{array}{c}0.554^{* *} \\
(0.256)\end{array}$ \\
\hline Deloitte ${ }^{*}$ Foreign Sales & $\begin{array}{c}0.035 \\
(0.298)\end{array}$ & $\begin{array}{c}0.637^{* *} \\
(0.299)\end{array}$ & $\begin{array}{l}0.995 * * * \\
(0.274)\end{array}$ \\
\hline KPMG * Foreign Sales & $\begin{array}{l}0.730^{* *} \\
(0.287)\end{array}$ & $\begin{array}{c}0.801 * * * \\
(0.304)\end{array}$ & $\begin{array}{c}0.847^{* * *} \\
(0.263)\end{array}$ \\
\hline PwC * Foreign Sales & $\begin{array}{l}0.697^{* *} \\
(0.307)\end{array}$ & $\begin{array}{c}0.228 \\
(0.308)\end{array}$ & $\begin{array}{c}0.664^{* *} \\
(0.289)\end{array}$ \\
\hline E\&Y * Debt & $\begin{array}{l}-0.272 \\
(0.343)\end{array}$ & $\begin{array}{l}-0.264 \\
(0.455)\end{array}$ & $\begin{array}{l}-0.808 \\
(0.503)\end{array}$ \\
\hline Deloitte $*$ Debt & $\begin{array}{l}-0.441 \\
(0.407)\end{array}$ & $\begin{array}{c}0.086 \\
(0.475)\end{array}$ & $\begin{array}{c}-0.667 \\
(0.474)\end{array}$ \\
\hline KPMG * Debt & $\begin{array}{l}-0.282 \\
(0.473)\end{array}$ & $\begin{array}{l}-0.195 \\
(0.538)\end{array}$ & $\begin{array}{l}-0.198 \\
(0.507)\end{array}$ \\
\hline $\mathrm{PwC} *$ Debt & $\begin{array}{c}0.218 \\
(0.461)\end{array}$ & $\begin{array}{l}-0.501 \\
(0.507)\end{array}$ & $\begin{array}{l}-0.827 \\
(0.508)\end{array}$ \\
\hline $\mathrm{E} \& \mathrm{Y} * \mathrm{ROA}$ & $\begin{array}{l}-1.022 * * * \\
(0.382)\end{array}$ & $\begin{array}{c}0.739 \\
(0.561)\end{array}$ & $\begin{array}{c}-1.062^{* *} \\
(0.513)\end{array}$ \\
\hline Deloitte * ROA & $\begin{array}{l}-0.092 \\
(0.528)\end{array}$ & $\begin{array}{c}0.838 \\
(0.637)\end{array}$ & $\begin{array}{c}-0.983^{*} \\
(0.595)\end{array}$ \\
\hline $\mathrm{KPMG} * \mathrm{ROA}$ & $\begin{array}{l}-0.857^{*} \\
(0.501)\end{array}$ & $\begin{array}{c}0.251 \\
(0.663)\end{array}$ & $\begin{array}{l}-0.690 \\
(0.637)\end{array}$ \\
\hline $\mathrm{PwC} * \mathrm{ROA}$ & $\begin{array}{l}-0.596 \\
(0.543)\end{array}$ & $\begin{array}{l}-0.859 \\
(0.605)\end{array}$ & $\begin{array}{l}-0.432 \\
(0.713)\end{array}$ \\
\hline $\mathrm{E} \& \mathrm{Y} *$ Inventory + Receivables & $\begin{array}{c}-1.345^{* *} \\
(0.598)\end{array}$ & $\begin{array}{c}-1.930^{* *} \\
(0.755)\end{array}$ & $\begin{array}{c}-1.762^{* *} \\
(0.725)\end{array}$ \\
\hline Deloitte ${ }^{*}$ Inventory + Receivables & $\begin{array}{l}-0.438 \\
(0.691)\end{array}$ & $\begin{array}{l}-1.373^{*} \\
(0.733)\end{array}$ & $\begin{array}{l}-0.958 \\
(0.721)\end{array}$ \\
\hline KPMG * Inventory + Receivables & $\begin{array}{l}-0.846 \\
(0.666)\end{array}$ & $\begin{array}{c}-1.814^{* *} \\
(0.774)\end{array}$ & $\begin{array}{l}-1.381^{*} \\
(0.708)\end{array}$ \\
\hline PwC * Inventory + Receivables & $\begin{array}{l}-1.297^{*} \\
(0.779)\end{array}$ & $\begin{array}{l}-1.034 \\
(0.808)\end{array}$ & $\begin{array}{c}-2.403^{* * * *} \\
(0.822)\end{array}$ \\
\hline E\&Y * Payables & $\begin{array}{l}-1.559^{*} \\
(0.845)\end{array}$ & $\begin{array}{c}0.162 \\
(0.993)\end{array}$ & $\begin{array}{l}-0.810 \\
(0.977)\end{array}$ \\
\hline Deloitte * Payables & $\begin{array}{l}-1.603^{*} \\
(0.964)\end{array}$ & $\begin{array}{l}-1.468 \\
(0.910)\end{array}$ & $\begin{array}{c}-1.942^{* *} \\
(0.837)\end{array}$ \\
\hline KPMG * Payables & $\begin{array}{c}-1.787^{* *} \\
(0.820)\end{array}$ & $\begin{array}{l}-1.115 \\
(0.848)\end{array}$ & $\begin{array}{l}-1.136 \\
(0.794)\end{array}$ \\
\hline PwC * Payables & $\begin{array}{c}0.142 \\
(1.144)\end{array}$ & $\begin{array}{c}0.107 \\
(1.064)\end{array}$ & $\begin{array}{c}-0.699 \\
(1.098)\end{array}$ \\
\hline $\mathrm{E} \& \mathrm{Y} * \operatorname{Ln}($ Years Client) & $\begin{array}{l}-0.111 \\
(0.197)\end{array}$ & $\begin{array}{l}-0.025 \\
(0.209)\end{array}$ & $\begin{array}{l}-0.028 \\
(0.264)\end{array}$ \\
\hline Deloitte ${ }^{*} \operatorname{Ln}($ Years Client) & $\begin{array}{c}0.093 \\
(0.207)\end{array}$ & $\begin{array}{c}0.321 \\
(0.219)\end{array}$ & $\begin{array}{c}0.799^{* * * *} \\
(0.258)\end{array}$ \\
\hline KPMG * Ln(Years Client) & $\begin{array}{l}0.397^{*} \\
(0.219)\end{array}$ & $\begin{array}{c}0.483^{* *} \\
(0.202)\end{array}$ & $\begin{array}{c}0.374 \\
(0.297)\end{array}$ \\
\hline PwC $*$ Ln(Years Client) & $\begin{array}{c}0.157 \\
(0.241)\end{array}$ & $\begin{array}{c}0.335 \\
(0.233)\end{array}$ & $\begin{array}{c}0.464 \\
(0.320)\end{array}$ \\
\hline E\&Y $*$ Not Prior Client & $\begin{array}{l}-5.873 * * * \\
(0.432)\end{array}$ & $\begin{array}{l}-6.233^{* * *} \\
(0.470)\end{array}$ & $\begin{array}{l}-6.167^{* * * *} \\
(0.599)\end{array}$ \\
\hline Deloitte $*$ Not Prior Client & $\begin{array}{c}-5.947^{* * *} \\
(0.446)\end{array}$ & $\begin{array}{c}-5.565^{* * *} \\
(0.479)\end{array}$ & $\begin{array}{c}-4.867^{* * * *} \\
(0.509)\end{array}$ \\
\hline KPMG $*$ Not Prior Client & $\begin{array}{l}-5.292^{* * *} \\
(0.444)\end{array}$ & $\begin{array}{l}-5.495^{* * *} \\
(0.422)\end{array}$ & $\begin{array}{l}-5.884^{* * * *} \\
(0.608)\end{array}$ \\
\hline PwC $*$ Not Prior Client & $\begin{array}{l}-6.191 * * * \\
(0.551)\end{array}$ & $\begin{array}{l}-5.496 * * * \\
(0.526)\end{array}$ & $\begin{array}{l}-5.849^{* * *} \\
(0.695)\end{array}$ \\
\hline $\begin{array}{l}\text { Industry Interactions with Brand Fixed Effects } \\
\text { Observations }\end{array}$ & $\begin{array}{c}\text { YES } \\
27,034\end{array}$ & $\begin{array}{c}\text { YES } \\
25,333\end{array}$ & $\begin{array}{c}\text { YES } \\
25,024\end{array}$ \\
\hline
\end{tabular}


Panel B: Mean price elasticities for all clients

\begin{tabular}{lccc}
\hline & 2008 & 2009 & 2010 \\
\hline E\&Y & -1.625 & -1.532 & -1.535 \\
Deloitte & -1.754 & -1.651 & -1.651 \\
KPMG & -1.757 & -1.652 & -1.647 \\
PwC & -1.728 & -1.633 & -1.630 \\
Other & -1.341 & -1.270 & -1.302 \\
\hline
\end{tabular}

Panel C: Mean price elasticities conditional on being a client of the audit firm in the prior year

\begin{tabular}{lccc}
\hline & 2008 & 2009 & 2010 \\
\hline E\&Y & -0.074 & -0.066 & -0.038 \\
Deloitte & -0.101 & -0.094 & -0.060 \\
KPMG & -0.086 & -0.089 & -0.043 \\
PwC & -0.055 & -0.066 & -0.034 \\
Other & -0.201 & -0.192 & -0.250 \\
\hline
\end{tabular}


Table 6: Model fit

This table compares actual auditor choices with the predicted choices based on the models presented in Table 5. The predicted choice is the auditor with the highest predicted probability for the client and the matrix pools actual and predicted choices over 2008-2010.

\begin{tabular}{lrrrrrr}
\hline & \multicolumn{7}{c}{ Highest Predicted Probability } \\
Acutal Choice & E\&Y & Deloitte & KPMG & PwC & non-Big 4 & Total \\
\hline E\&Y & 2,983 & 28 & 23 & 22 & 174 & 3,230 \\
& $92.4 \%$ & $0.9 \%$ & $0.7 \%$ & $0.7 \%$ & $5.4 \%$ & \\
Deloitte & 22 & 2,077 & 14 & 23 & 136 & 2,272 \\
& $1.0 \%$ & $91.4 \%$ & $0.6 \%$ & $1.0 \%$ & $6.0 \%$ & \\
KPMG & 26 & 19 & 2,073 & 9 & 150 & 2,277 \\
& $1.1 \%$ & $0.8 \%$ & $91.0 \%$ & $0.4 \%$ & $6.6 \%$ & \\
PwC & 21 & 24 & 18 & 2,258 & 126 & 2,447 \\
& $0.9 \%$ & $1.0 \%$ & $0.7 \%$ & $92.3 \%$ & $5.1 \%$ & \\
non-Big 4 & 56 & 48 & 36 & 38 & 5,088 & 5,266 \\
& $1.1 \%$ & $0.9 \%$ & $0.7 \%$ & $0.7 \%$ & $96.6 \%$ & \\
Total & & & & & & \\
& 3,108 & 2,196 & 2,164 & 2,350 & 5,674 & 15,492 \\
\hline
\end{tabular}


Table 7: Demand and Price Elasticity Estimates for Arthur Andersen Clients

This table presents demand estimates and price elasticity estimates for former Arthur Andersen clients in 2002. Panel A presents demand estimates: column (1) presents estimates of audit firm choice in 2002 for firms that were clients of Arthur Andersen in 2001; column (2) presents estimates of audit firm choice in 2001 for all firms; column 3 presents estimates of audit firm choice in 2002 for firms that were not clients of Arthur Andersen in 2001. For all three regressions, the outside good consists of the non-Big 4 audit firms. Ln(Predicted Fees) is the natural logarithm of predicted fees for each of the Big 4 audit firms. E\&Y, Deloitte, KPMG, and $\mathrm{PwC}$ are brand fixed effects for each of the Big 4 audit firms. Ln(Assets) is the natural logarithm of the client's total assets, $\operatorname{Ln}$ (Segments) is the natural logarithm of the client's industrial segments, Foreign Sales is the percentage of the clients sales generated outside of the US, Debt is the ratio of short- and long-term debt to total assets for the client, ROA is the client's return on assets, Inventory + Receivables is the client's ratio of inventory and receivables to total assets, and Payables is the ratio of the client's account payables to total assets. Not tabulated are interactions between the brand fixed effects and indicators for the Fama-French ten industries. Panel B presents price elasticity estimates for former Arthur Andersen clients based on the parameter estimates from the three regressions presented in Panel A. 
Panel A: Demand estimates for former Arthur Andersen clients in 2002

\begin{tabular}{|c|c|c|c|}
\hline & Andersen Clients & All Clients & No Andersen Clients \\
\hline Ln(Predicted Fees) & $\begin{array}{l}-2.283^{* * *} \\
(0.197)\end{array}$ & $\begin{array}{c}-2.058^{* * *} \\
(0.069)\end{array}$ & $\begin{array}{l}-2.009^{* * *} \\
(0.074)\end{array}$ \\
\hline E\&Y & $\begin{array}{l}-1.034 \\
(0.961)\end{array}$ & $\begin{array}{c}-1.053^{* * *} \\
(0.257)\end{array}$ & $\begin{array}{c}-1.088^{* * * *} \\
(0.271)\end{array}$ \\
\hline Deloitte & $\begin{array}{l}-2.277^{* *} \\
(1.007)\end{array}$ & $\begin{array}{c}-1.690^{* * *} \\
(0.269)\end{array}$ & $\begin{array}{l}-1.656^{* * *} * \\
(0.283)\end{array}$ \\
\hline KPMG & $\begin{array}{l}-1.403 \\
(0.965)\end{array}$ & $\begin{array}{l}-1.426^{* * *} \\
(0.256)\end{array}$ & $\begin{array}{l}-1.456^{* * *} \\
(0.269)\end{array}$ \\
\hline $\mathrm{PwC}$ & $\begin{array}{l}-1.264 \\
(1.015)\end{array}$ & $\begin{array}{l}-1.661^{* * *} \\
(0.263)\end{array}$ & $\begin{array}{l}-1.677^{* * * *} \\
(0.274)\end{array}$ \\
\hline $\mathrm{E} \& \mathrm{Y} * \operatorname{Ln}($ Assets $)$ & $\begin{array}{c}0.849^{* * *} \\
(0.166)\end{array}$ & $\begin{array}{c}0.662^{* * *} \\
(0.038)\end{array}$ & $\begin{array}{c}0.655^{* * *} * \\
(0.039)\end{array}$ \\
\hline Deloitte $* \operatorname{Ln}($ Assets $)$ & $\begin{array}{l}0.981 * * * \\
(0.171)\end{array}$ & $\begin{array}{l}0.650 * * * \\
(0.039)\end{array}$ & $\begin{array}{c}0.624 * * * \\
(0.040)\end{array}$ \\
\hline KPMG $* \operatorname{Ln}($ Assets $)$ & $\begin{array}{c}0.858 * * * \\
(0.167)\end{array}$ & $\begin{array}{c}0.646^{* * * *} \\
(0.038)\end{array}$ & $\begin{array}{c}0.631 * * * \\
(0.040)\end{array}$ \\
\hline $\mathrm{PwC} * \operatorname{Ln}$ (Assets) & $\begin{array}{c}0.871 * * * \\
(0.171)\end{array}$ & $\begin{array}{c}0.760^{* * * *} \\
(0.039)\end{array}$ & $\begin{array}{c}0.752^{* * * *} \\
(0.040)\end{array}$ \\
\hline $\mathrm{E} \& \mathrm{Y} * \operatorname{Ln}($ Segments $)$ & $\begin{array}{l}-0.079 \\
(0.251)\end{array}$ & $\begin{array}{l}-0.049 \\
(0.072)\end{array}$ & $\begin{array}{l}-0.097 \\
(0.076)\end{array}$ \\
\hline Deloitte $*$ Ln(Segments) & $\begin{array}{l}-0.158 \\
(0.260)\end{array}$ & $\begin{array}{l}-0.025 \\
(0.075)\end{array}$ & $\begin{array}{l}-0.048 \\
(0.079)\end{array}$ \\
\hline KPMG * Ln(Segments) & $\begin{array}{l}-0.606^{* *} \\
(0.254)\end{array}$ & $\begin{array}{c}-0.158^{* *} \\
(0.074)\end{array}$ & $\begin{array}{l}-0.130^{*} \\
(0.079)\end{array}$ \\
\hline PwC * Ln(Segments) & $\begin{array}{c}-0.567^{* *} \\
(0.267)\end{array}$ & $\begin{array}{l}-0.215^{* * *} \\
(0.074)\end{array}$ & $\begin{array}{l}-0.207^{* * *} \\
(0.077)\end{array}$ \\
\hline E\&Y $*$ Foreign Sales & $\begin{array}{l}-0.347 \\
(0.551)\end{array}$ & $\begin{array}{c}0.391^{* * *} \\
(0.148)\end{array}$ & $\begin{array}{c}0.437 * * * \\
(0.155)\end{array}$ \\
\hline Deloitte $*$ Foreign Sales & $\begin{array}{l}-0.284 \\
(0.576)\end{array}$ & $\begin{array}{l}0.340^{* *} \\
(0.158)\end{array}$ & $\begin{array}{l}0.388^{* *} \\
(0.165)\end{array}$ \\
\hline KPMG * Foreign Sales & $\begin{array}{c}0.214 \\
(0.548)\end{array}$ & $\begin{array}{c}0.780^{* * *} \\
(0.154)\end{array}$ & $\begin{array}{c}0.839^{* * *} \\
(0.163)\end{array}$ \\
\hline $\mathrm{PwC} *$ Foreign Sales & $\begin{array}{l}0.257 \\
(0.575)\end{array}$ & $\begin{array}{c}0.957 * * * \\
(0.151)\end{array}$ & $\begin{array}{l}0.974^{* * * *} \\
(0.157)\end{array}$ \\
\hline E\&Y * Debt & $\begin{array}{l}-1.719^{* *} \\
(0.760)\end{array}$ & $\begin{array}{c}-0.804^{* * *} \\
(0.214)\end{array}$ & $\begin{array}{l}-0.796^{* * *} \\
(0.228)\end{array}$ \\
\hline Deloitte $*$ Debt & $\begin{array}{r}-1.553^{*} \\
(0.819)\end{array}$ & $\begin{array}{l}-0.259 \\
(0.234)\end{array}$ & $\begin{array}{l}-0.215 \\
(0.248)\end{array}$ \\
\hline $\mathrm{KPMG} *$ Debt & $\begin{array}{l}-0.854 \\
(0.785)\end{array}$ & $\begin{array}{c}0.123 \\
(0.225)\end{array}$ & $\begin{array}{l}0.187 \\
(0.239)\end{array}$ \\
\hline $\mathrm{PwC} *$ Debt & $\begin{array}{l}-2.237 * * * \\
(0.837)\end{array}$ & $\begin{array}{c}-0.714^{* * *} \\
(0.223)\end{array}$ & $\begin{array}{c}-0.592^{* *} \\
(0.232)\end{array}$ \\
\hline $\mathrm{E} \& \mathrm{Y} * \mathrm{ROA}$ & $\begin{array}{l}0.725 \\
(0.759)\end{array}$ & $\begin{array}{c}-1.141^{* * *} \\
(0.247)\end{array}$ & $\begin{array}{c}-1.360^{* * *} * \\
(0.265)\end{array}$ \\
\hline Deloitte $*$ ROA & $\begin{array}{l}1.466^{*} \\
(0.865)\end{array}$ & $\begin{array}{l}-0.127 \\
(0.282)\end{array}$ & $\begin{array}{l}-0.287 \\
(0.301)\end{array}$ \\
\hline $\mathrm{KPMG} * \mathrm{ROA}$ & $\begin{array}{c}0.264 \\
(0.757)\end{array}$ & $\begin{array}{c}-0.920 * * * \\
(0.259)\end{array}$ & $\begin{array}{l}-1.002^{* * * *} \\
(0.281)\end{array}$ \\
\hline $\mathrm{PwC} * \mathrm{ROA}$ & $\begin{array}{l}1.290 \\
(0.845)\end{array}$ & $\begin{array}{c}-0.716^{* * *} \\
(0.261)\end{array}$ & $\begin{array}{c}-0.896 * * * \\
(0.278)\end{array}$ \\
\hline $\mathrm{E} \& \mathrm{Y} *$ Inventory + Receivables & $\begin{array}{c}0.900 \\
(1.167)\end{array}$ & $\begin{array}{c}-0.948^{* * *} \\
(0.282)\end{array}$ & $\begin{array}{c}-0.932^{* * *} \\
(0.294)\end{array}$ \\
\hline Deloitte ${ }^{*}$ Inventory + Receivables & $\begin{array}{l}1.009 \\
(1.246)\end{array}$ & $\begin{array}{l}-0.496 \\
(0.304)\end{array}$ & $\begin{array}{l}-0.471 \\
(0.317)\end{array}$ \\
\hline KPMG * Inventory + Receivables & $\begin{array}{l}1.692 \\
(1.166)\end{array}$ & $\begin{array}{l}-0.553^{*} \\
(0.286)\end{array}$ & $\begin{array}{c}-0.643^{* *} \\
(0.301)\end{array}$ \\
\hline PwC * Inventory + Receivables & $\begin{array}{l}2.325^{*} \\
(1.237)\end{array}$ & $\begin{array}{l}-0.761 * * * \\
(0.294)\end{array}$ & $\begin{array}{c}-0.897^{* * *} * \\
(0.305)\end{array}$ \\
\hline E\&Y * Payables & $\begin{array}{l}-2.890^{* *} \\
(1.330)\end{array}$ & $\begin{array}{l}-2.987^{* * *} \\
(0.355)\end{array}$ & $\begin{array}{l}-3.128^{* * * *} \\
(0.376)\end{array}$ \\
\hline Deloitte $*$ Payables & $\begin{array}{l}-3.846^{* * * *} \\
(1.431)\end{array}$ & $\begin{array}{c}-2.703^{* * *} \\
(0.366)\end{array}$ & $\begin{array}{l}-2.641 * * * \\
(0.383)\end{array}$ \\
\hline KPMG * Payables & $\begin{array}{l}-2.956^{* *} \\
(1.261)\end{array}$ & $\begin{array}{c}-2.577^{* * *} \\
(0.328)\end{array}$ & $\begin{array}{c}-2.544^{* * * *} \\
(0.347)\end{array}$ \\
\hline PwC * Payables & $\begin{array}{c}-3.994^{* * *} \\
(1.396)\end{array}$ & $\begin{array}{c}-3.656^{* * *} \\
(0.372)\end{array}$ & $\begin{array}{c}-3.730^{* * * *} \\
(0.392)\end{array}$ \\
\hline Observations & 3,784 & 28,854 & 25,070 \\
\hline Industry Interactions & Yes & Yes & Yes \\
\hline
\end{tabular}


Panel B: Mean price elasticity estimates for former Arthur Andersen clients in 2002

\begin{tabular}{lccc}
\hline & \multicolumn{3}{c}{ Demand Parameters Estimated Using } \\
& Andersen Clients & All Clients & non-Andersen Clients \\
\hline E\&Y & -1.622 & -1.567 & -1.539 \\
Deloitte & -1.806 & -1.714 & -1.681 \\
KPMG & -1.649 & -1.647 & -1.628 \\
PwC & -1.918 & -1.602 & -1.541 \\
Other & -2.135 & -1.701 & -1.646 \\
\hline
\end{tabular}


Table 8: Actual choices of Arthur Andersen clients compared to model predictions

This table compares predicted with actual auditor choices in 2002 for firms that were clients of Arthur Andersen in 2001. Panel A uses the highest predicted probability from the model estimated on all clients presented in column (1) of Table 7. Panel B uses the highest predicted probability based on the model estimated only on Arthur Andersen clients presented in column (2) of Table 7. Panel $\mathrm{C}$ uses the highest predicted probability from the model estimated on firms that were not Arthur Andersen clients presented in column (3) of Table 7.

Panel A: Conditional logit estimated on Arthur Andersen clients

\begin{tabular}{lrrrrrr}
\hline & \multicolumn{7}{c}{ Highest Predicted Probability } \\
Acutal Choice & E\&Y & Deloitte & KPMG & PwC & non-Big 4 & Total \\
\hline E\&Y & 138 & 24 & 48 & 3 & 6 & 219 \\
Deloitte & $63.0 \%$ & $11.0 \%$ & $21.9 \%$ & $1.4 \%$ & $2.7 \%$ & \\
& 39 & 75 & 31 & 11 & 2 & 158 \\
KPMG & $24.7 \%$ & $47.5 \%$ & $19.6 \%$ & $7.0 \%$ & $1.3 \%$ & \\
& 53 & 19 & 127 & 7 & 4 & 210 \\
PwC & $25.2 \%$ & $9.1 \%$ & $60.5 \%$ & $3.3 \%$ & $1.9 \%$ & \\
& 33 & 18 & 40 & 28 & 2 & 121 \\
non-Big 4 & $27.3 \%$ & $14.9 \%$ & $33.1 \%$ & $23.1 \%$ & $1.7 \%$ & \\
& 17 & 5 & 9 & 1 & 17 & 49 \\
Total & $34.7 \%$ & $10.2 \%$ & $18.4 \%$ & $2.0 \%$ & $34.7 \%$ & \\
& 280 & 141 & 255 & 50 & 31 & 757 \\
\hline
\end{tabular}

Panel B: Conditional logit estimated on all clients

\begin{tabular}{lrrrrrr}
\hline & \multicolumn{7}{c}{ Highest Predicted Probability } \\
Acutal Choice & E\&Y & Deloitte & KPMG & PwC & non-Big 4 & Total \\
\hline E\&Y & 132 & 12 & 17 & 41 & 17 & 219 \\
Deloitte & $60.3 \%$ & $5.5 \%$ & $7.8 \%$ & $18.7 \%$ & $7.8 \%$ & \\
& 37 & 66 & 14 & 34 & 7 & 158 \\
KPMG & $23.4 \%$ & $41.8 \%$ & $8.9 \%$ & $21.5 \%$ & $4.4 \%$ & \\
& 44 & 10 & 90 & 42 & 24 & 210 \\
PwC & $21.0 \%$ & $4.8 \%$ & $42.9 \%$ & $20.0 \%$ & $11.4 \%$ & \\
& 26 & 9 & 22 & 58 & 6 & 121 \\
non-Big 4 & $21.5 \%$ & $7.4 \%$ & $18.2 \%$ & $47.9 \%$ & $5.0 \%$ & \\
& 18 & 3 & 1 & 1 & 26 & 49 \\
& $36.7 \%$ & $6.1 \%$ & $2.0 \%$ & $2.0 \%$ & $53.1 \%$ & \\
Total & & & & & & \\
\hline
\end{tabular}


Panel C: Conditional logit estimated on non-Arthur Andersen clients

\begin{tabular}{lrrrrrr}
\hline & \multicolumn{7}{c}{ Highest Predicted Probability } \\
Acutal Choice & E\&Y & Deloitte & KPMG & PwC & non-Big 4 & Total \\
\hline E\&Y & 119 & 10 & 17 & 53 & 20 & 219 \\
& $54.3 \%$ & $4.6 \%$ & $7.8 \%$ & $24.2 \%$ & $9.1 \%$ & \\
Deloitte & 34 & 63 & 12 & 42 & 7 & 158 \\
& $21.5 \%$ & $39.9 \%$ & $7.6 \%$ & $26.6 \%$ & $4.4 \%$ & \\
KPMG & 41 & 4 & 87 & 52 & 26 & 210 \\
& $19.5 \%$ & $1.9 \%$ & $41.4 \%$ & $24.8 \%$ & $12.4 \%$ & \\
PwC & 27 & 9 & 16 & 62 & 7 & 121 \\
& $22.3 \%$ & $7.4 \%$ & $13.2 \%$ & $51.2 \%$ & $5.8 \%$ & \\
non-Big 4 & 18 & 1 & 1 & 2 & 27 & 49 \\
& $36.7 \%$ & $2.0 \%$ & $2.0 \%$ & $4.1 \%$ & $55.1 \%$ & \\
Total & & & & & & \\
\hline
\end{tabular}


Table 9: Disappearance of a Big 4 audit firm with no supply response

The table presents expected changes in consumer surplus if one of the Big 4 audit firms disappeared. Estimates are based on Table 5 coefficient estimates for 2008, 2009, and 2010. For the disappearance of each of the Big 4 audit firms, we estimate the expected change in consumer surplus, $C_{i j m}$, for each firm i. To do so, we draw vectors of type 1 extreme value error terms - one for each of the Big 4 auditors and one for the outside good. For each vector draw, we combine in equation (1) the parameter estimates from the demand estimation along with the the firm-auditor characteristics and the error term draw to calculate the utility that client would receive from choosing each of the Big 4 auditors and the outside good. We then pick the audit firm that leads to maximum utility under this unrestricted choice set. We next restrict the choice set for each client (i.e., remove one of the Big 4 auditors) and calculate the maximum utility that the client would have received under the restricted choice set. Then, we solve for the change in consumer surplus $C_{i j m}$ that equates the maximum utilities. For each client, we repeat this procedure 1,000 times and take the average of the required dollar transfer to create $E\left[C_{i j m}\right]$. Panel A presents the estimates of the expected total change in consumer surplus if each of the Big 4 disappears. Panel B presents the firm-level mean change in consumer surplus and correlations of the firm-level change in consumer surplus with firm size, audit fees, and tenure with auditor.

Panel A: Total expected changes in consumer surplus if one of the Big 4 audit firms disappears (US\$ in billions)

\begin{tabular}{lccc}
\hline & 2008 & 2009 & 2010 \\
\hline E\&Y & 1.548 & 1.517 & 1.646 \\
Deloitte & 1.334 & 1.247 & 1.386 \\
KPMG & 1.234 & 1.192 & 1.278 \\
PwC & 1.657 & 1.540 & 1.794 \\
\hline
\end{tabular}




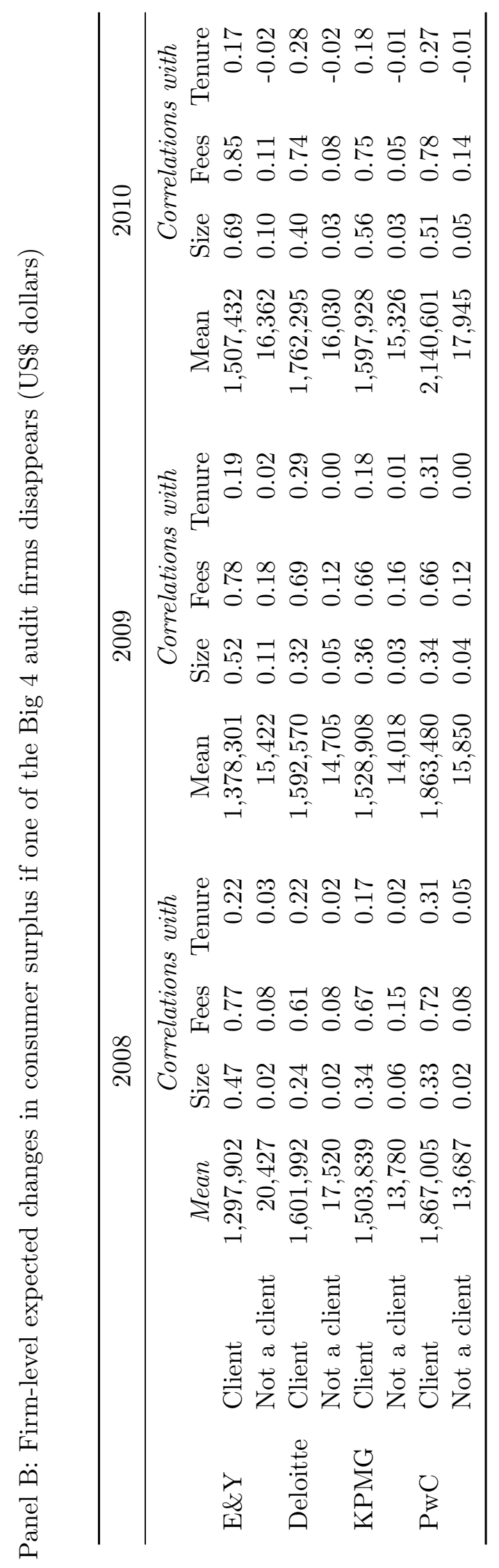


Table 10: Mandatory audit firm rotation with no supply response

The table presents expected changes in consumer surplus if mandatory audit firm rotation were to be implemented after four through ten years. Estimates are based on Table 5 coefficient estimates for 2008, 209, and 2010, and are denominated in billions of US dollars. For the implementation of mandatory audit firm rotation at various tenures, we remove an auditor from the client's choice set if the length of the auditor-client relationship was equal to or greater than the specified number of years that require mandatory rotation and then estimate the expected change in consumer surplus, $C_{i j m}$, for each firm i. To do so, we draw vectors of type 1 extreme value error terms - one for each of the Big 4 auditors and one for the outside good. For each vector draw, we combine in equation (1) the parameter estimates from the demand estimation along with the the firm-auditor characteristics and the error term draw to calculate the utility that client would receive from choosing each of the Big 4 auditors and the outside good. We then pick the audit firm that leads to maximum utility under this unrestricted choice set. We next restrict the choice set for each client based on mandatory audit firm rotation and calculate the maximum utility that the client would have received under the restricted choice set. Then, we solve for the change in consumer surplus $C_{i j m}$ that equates the maximum utilities. For each client, we repeat this procedure 1,000 times and take the average of the required dollar transfer to create $E\left[C_{i j m}\right]$. Panel A presents the estimates of the expected total change in consumer surplus for mandatory audit firm rotation. Panel B presents the firm-level mean change in consumer surplus and correlations of the firm-level change in consumer surplus with firm size, audit fees, and tenure with auditor.

Panel A: Changes in consumer surplus if mandatory audit firm rotation is implemented (US\$ in billions)

\begin{tabular}{lccc}
\hline & 2008 & 2009 & 2010 \\
\hline Four years & 4.298 & 4.260 & 5.039 \\
Five years & 4.067 & 4.018 & 4.425 \\
Six years & 3.156 & 3.828 & 4.191 \\
Seven years & 2.918 & 3.010 & 3.997 \\
Eight years & 2.733 & 2.776 & 3.191 \\
Nine years & 2.547 & 2.586 & 2.966 \\
Ten years & 2.363 & 2.419 & 2.761 \\
\hline
\end{tabular}




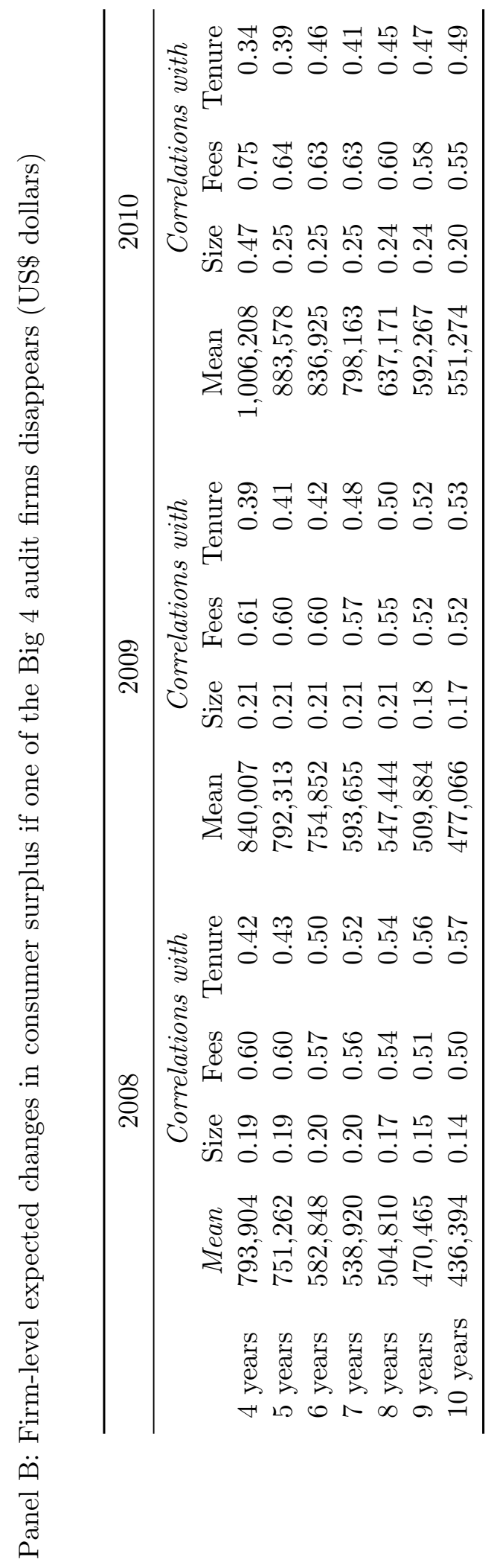


Table 11: Supply response for the disappearance of a Big 4 audit firm

This table presents estimates of the increase in total annual audit fees if one of the Big 4 audit firms disappears. To calculate this expected supply side response, we estimate the semi-elasticity of audit fees in 2002 with respect to the percent share of industry total assets audited by Arthur Andersen in 2001 based on three-digit SIC. This semi-elasticity is a $0.15 \%$ increase in audit fees for each one percentage point of total industry assets audited by Arthur Andersen. For each counterfactual, we calculate by three-digit SIC the percentage of total assets audited by the disappearing Big 4 audit firm. For each client, we then calculate the expected increase in annual audit fees based on the client's actual audit fees times the semi-elasticity times the percentage of industry assets audited by the disappearing firm. The columns present sums by year denominated in billions of US $\$$.

\begin{tabular}{lccc}
\hline & 2008 & 2009 & 2010 \\
\hline E\&Y & 0.456 & 0.426 & 0.415 \\
Deloitte & 0.408 & 0.369 & 0.362 \\
KPMG & 0.397 & 0.346 & 0.335 \\
PwC & 0.533 & 0.486 & 0.497 \\
\hline
\end{tabular}


Table 12: Supply response for implementation of mandatory audit firm rotation

This table presents estimates of the increase in total annual audit fees if mandatory audit firm rotation were to be implemented. To calculate this expected supply side response, we estimate the semi-elasticity of audit fees in 2002 with respect to the percent share of industry total assets audited by Arthur Andersen in 2001 based on three-digit SIC. This semi-elasticity is a $0.15 \%$ increase in audit fees for each one percentage point of total industry assets audited by Arthur Andersen. For each counterfactual, we calculate by three-digit SIC the percentage of total assets subject to mandatory audit firm rotation. For each client, we then calculate the expected increase in annual audit fees based on the client's actual audit fees times the semi-elasticity times the percentage of industry assets subject to mandatory audit firm rotation. The columns present sums by year of the increases in audit fees denominated in billions of US\$.

\begin{tabular}{lccc}
\hline & 2008 & 2009 & 2010 \\
\hline Four years & 1.337 & 1.227 & 1.336 \\
Five years & 1.302 & 1.178 & 1.160 \\
Six years & 1.065 & 1.145 & 1.119 \\
Seven years & 1.004 & 0.931 & 1.090 \\
Eight years & 0.915 & 0.878 & 0.893 \\
Nine years & 0.839 & 0.801 & 0.848 \\
Ten years & 0.786 & 0.755 & 0.772 \\
\hline
\end{tabular}




\section{APPENDIX}

\section{A Predicting audit fees}

To evaluate the best method to predict audit fees, we compared six regression methods that are commonly used in forecasting applications: ordinary least squares ols, lasso regression lasso, ridge regression ridge, partial least squares pls, recursive partitioning rpart, and randomForest rfor. ${ }^{19}$ For each auditor-year pair, we used the six regression methods to generate RMSEs using 100 repetitions of five-fold cross-validations. As predictors of audit fees, we include the natural logarithm of total assets, the natural logarithm of industrial segments, the percentage of foreign sales, the ratio of debt to total assets, the ratio of inventory and receivables to total assets, the ratios of payables to total assets, the number of years as client of the audit firm, indicator variables for the Fama-French ten industry classification, the ratio of three-digit SIC industry assets audited by Arthur Andersen in 2001, and the ratio of three-digit SIC industry assets merged in the prior year. Table A.1 presents the distribution of the minimum RMSEs by regression method for each auditor-year pair. As shown in the far right column, randomForest has the highest number of minimum RMSEs for each auditor-year pair. We therefore use randomForest to predict the audit fees that we use in our demand estimations.

\footnotetext{
${ }^{19}$ For a description of these methods, see Hastie, Tibshirani, and Friedman (2009).
} 
Table A.1: Comparison of lowest RMSEs for the prediction methods

\begin{tabular}{|c|c|c|c|c|c|c|c|}
\hline & & ols & lasso & ridge & $\mathrm{pls}$ & rpart & rfor \\
\hline \multirow[t]{10}{*}{$\mathrm{E} \& \mathrm{Y}$} & 2002 & 7,052 & 14,527 & 6,986 & 11,797 & 40,273 & 57,165 \\
\hline & 2003 & 8,439 & 15,497 & 6,844 & 14,356 & 41,138 & 50,526 \\
\hline & 2004 & 9,819 & 19,561 & 5,733 & 13,054 & 35,899 & 41,534 \\
\hline & 2005 & 8,785 & 16,248 & 5,766 & 12,726 & 36,001 & 44,074 \\
\hline & 2006 & 8,053 & 20,296 & 6,098 & 10,284 & 33,990 & 42,179 \\
\hline & 2007 & 7,525 & 19,283 & 5,895 & 11,628 & 32,951 & 42,018 \\
\hline & 2008 & 7,133 & 17,725 & 4,723 & 8,956 & 31,682 & 42,281 \\
\hline & 2009 & 5,364 & 16,310 & 4,659 & 8,379 & 29,763 & 41,125 \\
\hline & 2010 & 5,620 & 16,582 & 4,837 & 8,466 & 29,608 & 39,787 \\
\hline & 2011 & 5,986 & 14,847 & 4,677 & 7,667 & 30,661 & 40,062 \\
\hline \multirow[t]{10}{*}{ Deloitte } & 2002 & 6,448 & 13,228 & 4,644 & 7,153 & 27,114 & 37,913 \\
\hline & 2003 & 6,064 & 11,441 & 5,405 & 8,383 & 26,016 & 39,491 \\
\hline & 2004 & 6,281 & 10,826 & 5,672 & 9,955 & 23,609 & 37,157 \\
\hline & 2005 & 6,414 & 11,459 & 5,414 & 8,955 & 24,945 & 34,413 \\
\hline & 2006 & 6,492 & 11,634 & 5,152 & 8,499 & 24,782 & 29,641 \\
\hline & 2007 & 7,438 & 13,177 & 4,864 & 8,485 & 23,531 & 25,705 \\
\hline & 2008 & 6,151 & 11,671 & 4,153 & 8,301 & 22,443 & 25,481 \\
\hline & 2009 & 6,306 & 9,718 & 4,811 & 6,628 & 22,717 & 24,120 \\
\hline & 2010 & 5,426 & 9,626 & 4,266 & 6,427 & 24,143 & 24,912 \\
\hline & 2011 & 5,258 & 9,598 & 3,815 & 6,643 & 22,371 & 23,915 \\
\hline \multirow[t]{10}{*}{ KPMG } & 2002 & 6,051 & 8,683 & 5,648 & 9,230 & 26,324 & 59,164 \\
\hline & 2003 & 5,213 & 9,793 & 4,996 & 8,888 & 31,960 & 52,350 \\
\hline & 2004 & 6,199 & 12,808 & 5,421 & 10,076 & 28,522 & 44,274 \\
\hline & 2005 & 7,230 & 9,934 & 6,851 & 9,198 & 25,141 & 38,546 \\
\hline & 2006 & 5,735 & 12,113 & 5,149 & 9,802 & 21,771 & 35,930 \\
\hline & 2007 & 5,345 & 10,803 & 4,945 & 7,757 & 20,623 & 33,627 \\
\hline & 2008 & 5,442 & 8,875 & 4,365 & 6,579 & 20,114 & 32,425 \\
\hline & 2009 & 4,872 & 7,573 & 4,619 & 6,475 & 20,160 & 30,301 \\
\hline & 2010 & 4,972 & 8,627 & 3,853 & 6,203 & 22,286 & 29,959 \\
\hline & 2011 & 5,367 & 7,961 & 3,879 & 6,536 & 20,795 & 32,462 \\
\hline \multirow[t]{10}{*}{$\mathrm{PwC}$} & 2002 & 6,961 & 17,443 & 5,662 & 9,398 & 34,678 & 53,758 \\
\hline & 2003 & 8,973 & 15,585 & 6,148 & 10,182 & 36,128 & 50,884 \\
\hline & 2004 & 9,066 & 15,174 & 7,168 & 12,299 & 32,980 & 42,913 \\
\hline & 2005 & 9,243 & 15,393 & 5,936 & 11,516 & 28,421 & 35,491 \\
\hline & 2006 & 6,885 & 13,289 & 5,424 & 8,530 & 28,290 & 34,082 \\
\hline & 2007 & 5,637 & 12,099 & 4,938 & 8,554 & 26,273 & 32,699 \\
\hline & 2008 & 5,354 & 10,550 & 3,974 & 7,497 & 24,277 & 33,748 \\
\hline & 2009 & 5,066 & 8,658 & 4,168 & 7,908 & 23,532 & 29,668 \\
\hline & 2010 & 5,013 & 8,786 & 4,675 & 8,041 & 24,963 & 28,822 \\
\hline & 2011 & 6,454 & 10,121 & 4,709 & 6,217 & 23,965 & 29,534 \\
\hline \multirow[t]{10}{*}{ All others } & 2002 & 6,624 & 10,813 & 6,575 & 10,247 & 23,850 & 42,091 \\
\hline & 2003 & 7,028 & 12,860 & 6,163 & 11,566 & 34,494 & 43,889 \\
\hline & 2004 & 11,855 & 17,922 & 9,527 & 17,308 & 32,446 & 50,542 \\
\hline & 2005 & 16,953 & 26,375 & 10,262 & 22,586 & 40,643 & 52,781 \\
\hline & 2006 & 16,815 & 30,692 & 12,659 & 24,037 & 44,886 & 56,711 \\
\hline & 2007 & 17,785 & 29,676 & 12,794 & 28,026 & 49,456 & 59,163 \\
\hline & 2008 & 19,538 & 31,750 & 11,596 & 25,788 & 42,475 & 56,353 \\
\hline & 2009 & 18,968 & 28,884 & 11,251 & 22,235 & 42,921 & 49,941 \\
\hline & 2010 & 16,587 & 28,409 & 11,369 & 21,087 & 41,029 & 46,419 \\
\hline & 2011 & 14,718 & 24,971 & 10,110 & 19,030 & 37,538 & 47,333 \\
\hline
\end{tabular}


Table A.2: Distribution of Audit Fees

This table presents annual mean and median audit fees for our sample of SEC registrants. Panel A reports the means and medians for all sample firms, while Panel B reports the annual mean and median fees for a constant subsample of firms that appear in the sample every year. Audit fees are taken from the Audit Analytics database.

Panel A: Full sample

\begin{tabular}{rrrr}
\hline Year & Firms & \multicolumn{1}{c}{ Mean } & Median \\
\hline 2002 & 5,775 & 890,263 & 237,000 \\
2003 & 5,907 & $1,076,897$ & 296,900 \\
2004 & 5,856 & $1,753,816$ & 545,388 \\
2005 & 5,877 & $1,893,852$ & 640,000 \\
2006 & 5,799 & $2,149,814$ & 712,206 \\
2007 & 5,727 & $2,134,638$ & 740,659 \\
2008 & 5,414 & $2,225,593$ & 752,250 \\
2009 & 5,071 & $2,148,250$ & 735,000 \\
2010 & 5,008 & $2,150,459$ & 735,000 \\
\hline
\end{tabular}

Panel B: Fixed Sample

\begin{tabular}{rrcr}
\hline Year & Firms & Mean & \multicolumn{1}{c}{ Median } \\
\hline 2002 & 2,567 & $1,118,127$ & 283,800 \\
2003 & 2,567 & $1,406,201$ & 363,000 \\
2004 & 2,567 & $2,299,959$ & 721,050 \\
2005 & 2,567 & $2,532,946$ & 837,066 \\
2006 & 2,567 & $2,816,801$ & 951,600 \\
2007 & 2,567 & $2,871,367$ & 996,000 \\
2008 & 2,567 & $2,960,644$ & $1,000,000$ \\
2009 & 2,567 & $2,869,934$ & 964,960 \\
2010 & 2,567 & $2,846,895$ & 942,000 \\
\hline
\end{tabular}


Table A.3: Semi-elasticity of audit fees to changes in three-digit SIC audit firm market share

\begin{tabular}{lc}
\hline Andersen's Industry Share in 2001 & $0.0015^{* *}$ \\
& $(0.001)$ \\
Ln(Assets) & $0.4733^{* * *}$ \\
& $(0.006)$ \\
Receivables to Assets & $-0.4083^{* * *}$ \\
& $(0.051)$ \\
Inventory to Assets & $0.7668^{* * *}$ \\
& $(0.071)$ \\
Return on Assets & $-0.3357^{* * *}$ \\
& $(0.053)$ \\
Loss & $0.1780^{* * *}$ \\
& $(0.025)$ \\
Percent Foreign Sales & $0.5504^{* * *}$ \\
& $(0.022)$ \\
Ln(Segments) & $0.2156^{* * *}$ \\
Accelerated Filer & $(0.011)$ \\
& $-0.1614^{* * *}$ \\
Going Concern Opinion & $(0.025)$ \\
& $0.1978^{* * *}$ \\
Constant & $(0.048)$ \\
& \\
Observations & $9.3935^{* * *}$ \\
Adjusted $R^{2}$ & $(0.044)$ \\
\hline$* * *$ p $<0.01, * *$ p $<0.05, * 0.1$ & \\
&
\end{tabular}




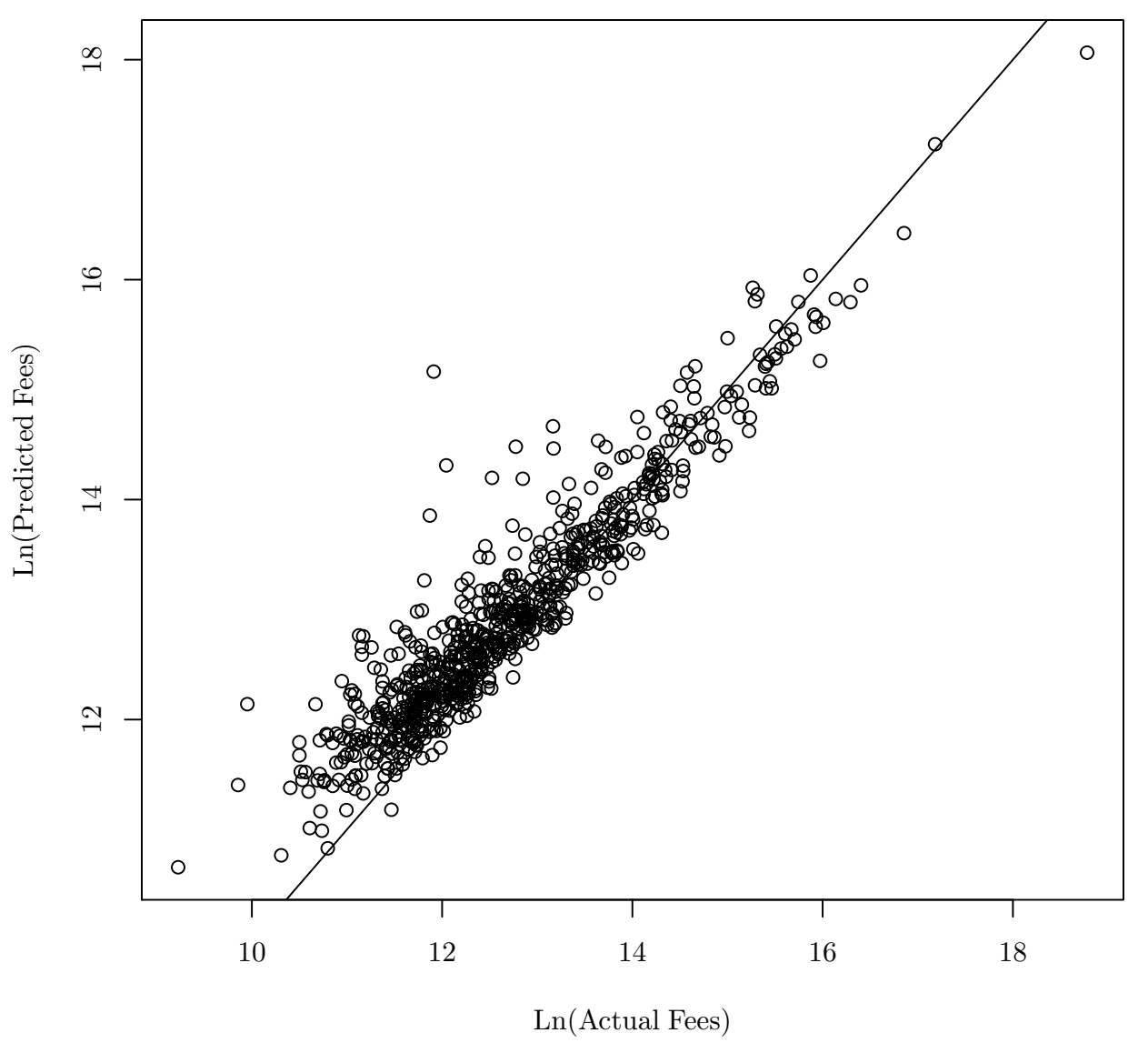

Figure A.1: Actual versus predicted fees This figure plots predicted versus actual log audit fees. 